\title{
The Democratic Window of Opportunity: Evidence from Riots in sub-Saharan Africa*
}

\author{
Toke S. Aidt ${ }^{\dagger}$ \\ Gabriel Leon \\ University of Cambridge University of Cambridge
}

June 24, 2014

\begin{abstract}
We show that drought-induced changes in the intensity of riots lead to moves towards democracy in sub-Saharan Africa, and that these changes are often a result of concessions made as a result of the riots. This provides evidence that low-intensity conflict can have a substantial short-run impact on democratic change, and supports the "window of opportunity" hypothesis: droughts lead to an increase in the threat of conflict, and incumbents often respond by making democratic concessions.
\end{abstract}

JEL: D7, P16

Keywords: Riots, drought, transitions, democracy, autocracy.

${ }^{*}$ We are grateful to Filipe Campante, Quoc-Anh Do, Markus Brückner and Antonio Ciccone for sharing their data with us. We thank Pramila Krishnan, Jane Cooley Fruehwirth, Hamish Low, Julia Shvets, Hector Calvo Pardo and seminar participants at Cambridge for helpful comments and suggestions.

${ }^{\dagger}$ Faculty of Economics and Jesus College, University of Cambridge, Cambridge CB3 9DD, United Kingdom. E-mail: toke.aidt@econ.cam.ac.uk. Phone: +44 1223 335231; and CESifo Munich.

${ }^{\ddagger}$ Faculty of Economics and St Catharine’s College, University of Cambridge, Cambridge CB3 9DD, United Kingdom. E-mail: gj138@cam.ac.uk. 


\section{Introduction}

What determines a country's political institutions, and in particular, the extent to which they are democratic? ${ }^{1}$ An important set of explanations has focused on the idea that conflict, or the possibility of conflict, induces leaders to promote institutional change. Tilly (1990), Besley and Persson (2008, 2009) and Dincecco and Prado (2012) argue that conflict, and in particular wars between countries, created the setting for Western European nations to build institutions that would enable the enforcement of contracts and collection of taxes. Conflict also plays an important role in Acemoglu and Robinson's $(2000,2001,2006)$ theory of democratization; they emphasize how the threat of conflict, in the form of a revolution, induces autocrats to make democratic concessions in an attempt to defuse that threat. In their theory revolutions are more likely in times of economic hardship, so negative economic shocks open a "window of opportunity" that can lead to a peaceful transition towards democracy.

In this paper we test the hypothesis that low-intensity conflict (riots) leads to democratic reform, and that this often happens through concessions made in response to the riots. The events in Togo in 1991 illustrate this mechanism. As Piot (2010) explains, "[i]n Togo in summer 1991, after months of clashes on the streets between dissidents and the military, Eyadéma capitulated to calls for a national conference to discuss steps toward democratization" (p.31). Meredith (2005) concurs that the riots put pressure on president Eyadéma: "[a]fter months of strikes, demonstrations and violence, Eyadéma agreed in April 1991 to allow opposition parties to operate and in July yielded to demands for a national conference" (p.397). The concessions were partial, however: "[a]t the end of the national conference in 1991, Eyadéma cleverly headed off an attempt by the political opposition to strip him of power ... but agreed to hold presidential elections" (Piot, p.33). Fearing electoral fraud, the opposition boycotted the election and allowed Eyadéma to win with 96 percent of the vote (Piot, $33)$.

The main difficulty in testing whether conflict opens a "window of opportunity" is 
that riots are rarely exogenous: there might be problems of reverse causality because the expectation of political change might itself lead to riots, and there might be unobservable omitted variables that cause both riots and political change. We address these technical problems by using droughts to create an instrumental variable for riots, as there is a considerable amount of case study evidence that shows that droughts often trigger social unrest in poor countries (see, for example, Walton and Seddon (1994)). ${ }^{2}$

To test the hypothesis that riots lead to democratic change we focus on sub-Saharan Africa in the period between 1990 and 2007. This choice is motivated by the large number of democratic (and anti-democratic) transitions that took place in that part of world during the sample period, and by the fact that drought is a particularly relevant instrument for this subset of countries. ${ }^{3}$ We use data on democratic change from the Polity IV project (Marshall and Jaggers, 2005) and geographical data on riots from the Social Conflict in Africa Database (Hendrix and Salehyan, 2011).

Our instrumental variables estimates show a strong first stage relationship between drought and riots, and represent empirical evidence that droughts lead to an increase in riots. We then find a significant second stage relationship between (instrumented) riots and democratic change. The magnitude of the effect is substantial; for example, some of our estimates suggest that the probability of a democratic change in the average country in the sample increases by 16.7 percentage points (from a baseline probability of $5.7 \%$ ) as a consequence of the impact a drought has on riots. Naturally, finding that riots lead to changes in democracy does not show that this is because governments feel threatened and make concessions, as suggested by the theory and the events in Togo discussed above. To address this concern, we restrict our attention to instances of democratic change that can be explicitly associated with concessions made by the incumbent government. ${ }^{4}$ This provides strong evidence that riots can lead to democratic change because incumbent governments are induced to make democratic concessions. This channel is different from that emphasized in the previous literature (e.g. Burke and Leigh, 2010; Brückner and Ciccone, 2011), where democratic change happens when its opportunity cost is low, as measured by GDP per capita. 
These results provide new evidence that low-intensity conflict can lead to democratic change over relatively short periods of time. These results are consistent with the causal mechanism underlying Acemoglu and Robinson's (2000, 2001, 2006) theory of political transitions, where the threat of a revolution induces autocratic rulers to make democratic concessions. Rioting and popular protest represent a threat to autocratic rulers, and may signal that the democratic "window of opportunity" is open. This might be because riots could unintentionally degenerate into a regime challenge (e.g., if rioters storm the presidential palace), or because the political opposition might use them for this purpose (e.g. to try to start a revolution). In either case, the incumbent government might react to this increased threat by making democratic concessions.

Our paper is related to a large literature that examines the relationship between international conflict and institutions. Tilly (1990), Hoffman and Rosenthal (1997) and O'Brien (2011) argue that Western European institutions for tax collection were created as a result of the need to pay for the costs of war. More recently, Besley and Persson (2008, 2009, 2010, 2011) have developed a theory of institutional development where conflict plays a central role. Dincecco, Federico and Vindigni (2011) and Dincecco and Prado (2012) provide empirical support for the link between conflict, fiscal capacity and institutional change. Our paper contributes to this literature, but differs in that it focuses on Africa (while most of the literature focuses on Western Europe), looks at a more recent historical period, examines the short-term rather than long-term impact of conflict on institutional change, and emphasizes the role of the threat of internal conflict instead of the threat of international wars.

This paper also relates to a small but growing empirical literature on the threat of revolution and democratization. Przeworski (2009) uses data on riots, demonstrations and strikes to study the correlation between franchise extensions and the threat of revolution in a broad world sample starting in 1918. Aidt and Jensen (2011) take a longer historical perspective and use the international diffusion of information about revolutionary events in Europe between 1820 and 1938 to study the causal link between revolutionary threats and suffrage reform. Both studies find evidence supporting Acemoglu 
and Robinson's (2000) theory of democratization. None of these papers, however, explore the association between temporary economic shocks, riots, and democratization. ${ }^{5}$ Burke and Leigh (2010) use information about anti-government protests reported in the New York Times to study the link between riots and democratic change in a world sample of countries, but cannot properly identify the effect. Using more detailed riots data for Africa and an instrumental variables approach, we can identify the causal impact riots have on democratic change.

Finally, our paper is also related to the large literature on adverse economic conditions and political change (e.g. Burke and Leigh, 2010; Brückner and Ciccone, 2011), and on economic shocks and civil conflict (e.g. Collier and Hoeffler, 1998, 2004; Miguel, Satyanath and Sergenti, 2004; Jensen and Gleditsch, 2009; Brückner and Ciccone, 2010). Brückner and Ciccone (2011) and Burke and Leigh (2010) use rainfall shocks to identify when and where the democratic "window of opportunity" might be open. Brückner and Ciccone (2011) establish a causal link between negative rainfall shocks and democratic change in sub-Saharan Africa, suggesting that this happens because rainfall shocks reduce real GDP per capita, which in turn reduces the opportunity cost of contesting power; Barron, Miguel and Satyanath (2013) discuss the robustness of these results. Burke and Leigh (2010) study a broader sample of countries and find results similar to those in Brückner and Ciccone (2011). ${ }^{6}$ Miguel, Satyanath and Sergenti (2004) use rainfall as an instrument for economic growth to establish a causal link between (the lack of) economic growth and civil conflict. ${ }^{7}$

The rest of this paper is organized as follows. Section 2 discusses the theoretical framework. Section 3 presents the data, while section 4 lays out our empirical strategy. Section 5 presents and discusses our main results, and section 6 concludes.

\section{Theoretical Framework}

The idea that the threat of social conflict is linked in a causal way to democratic change has a long history in political economy, and has recently gained renewed cur- 
rency through the work of Acemoglu and Robinson (2000, 2001, 2006) and Boix (2003). The formalization of this idea in the work by Acemoglu and Robinson emphasizes the notion of a "window of opportunity" for democratic reform. Their theory starts from the premise that incumbent rulers are unwilling to share power with other groups because this compromises their policy objectives. Consequently, democratic reform only happens in situations where opposition groups pose a threat to the status quo that is seen as credible by the incumbents. In some cases the incumbents perceive a need to act preemptively in order to avoid radical political change. Sharing power through democratic reform is, of course, only one alternative amongst many open to the incumbents. Repression or policy concessions are often sufficient and typically preferable, but sometimes more durable institutional change is required as the lesser of multiple evils. A key element in this theory is that institutional reforms are durable, so that they cannot be easily reversed once the threat that triggered them has subsided. History contains numerous instances in which reforms were undertaken under threat but were subsequently rolled back; the "Arab Spring" is perhaps the most recent example. These instances do not undermine the logic of the theory; what matters is that at the time they were made, the concessions were considered of sufficient duration to dissuade opposition groups from overthrowing the regime. Acemoglu and Robinson (2001) develop this logic in a formal model where democratic concessions can be reversed; in practice what makes democratic change more durable than other types of concessions is that it involves a change in institutions. This does not make it impossible to revert to the ex-ante status quo, but it does increase the cost of doing so.

An important insight that follows from this theory is that the threat posed by opposition groups is not always credible, but when it is, a "window of opportunity" is open. Acemoglu and Robinson (2001), Burke and Leigh (2010), and Brückner and Ciccone (2011) associate the "window of opportunity" with temporary adverse economic shocks that lower the cost of contesting power, allowing opposition groups to credibly threaten to overthrow the incumbents. We build on this idea but add an important new dimension that is at the center of our empirical analysis. Acemoglu 
and Robinson $(2000,2001,2006)$ assume that whether the "window of opportunity" is open is common knowledge to all parties. This assumption is challenged in the work by Andrews and Jackson (2005), among others, who point out that institutional reform typically takes place under conditions of extreme uncertainty. In essence this means that nobody can be entirely certain that the "window of opportunity" is open, and at any given point in time incumbents and opposition groups must act taking cues from events as they unfold. This insight, on the one hand, allows us to conjecture a link between these cues and democratic change: we argue that riots which have not yet escalated into a full-blown regime challenge but which have the potential do so are important cues that may induce democratic concessions. ${ }^{8}$ On the other hand, allowing for uncertainty introduces the new and important possibility that riots may develop into full-blown revolutions or civil wars; this may happen, for example, if incumbents underestimate the threat and fail to act in time to avoid it. ${ }^{9}$

We argue that riots, although often triggered by adverse economic shocks (e.g. droughts), can affect regime transitions through channels other than the opportunity cost mechanism stressed in the previous literature (and captured by fluctuations in official GDP per capita data). For example, in poor countries with large informal sectors where a large fraction of the population lives near the subsistence level in the countryside, negative weather shocks can lead to large population movements that might trigger riots and induce democratic concessions.

In short, we can summarize our theory as follows: incumbents will only share power if they perceive that opposition groups pose a credible threat. They use cues from unfolding events to assess whether they need to act in order to preserve their power. One important cue is low-intensity social unrest (e.g. riots) triggered by droughts. Based on this logic, we hypothesize that riots induced by drought may result in democratic concessions even if GDP per capita stays constant. We interpret this as a more refined version of the "window of opportunity" theory of democratic change than the one tested elsewhere in the literature. 


\section{Data}

Our dataset combines information on democratic change, riots, droughts, and economic conditions for a sample of 41 sub-Saharan African countries over the period 1990 to 2007. ${ }^{10}$ As many previous studies, we draw on the Polity IV database to measure changes in democracy (Marshall and Jaggers, 2005). ${ }^{11}$ We use this database to construct three different measures of democratic change. The starting point for our first two measures is the variable regtrans. This variable indicates whether a regime transition has begun in a given year; it can take a number of different values, with the value repeated in every year of the transition. Following Burke and Leigh (2010), we only count transitions in the first year in which they occur, setting the regtrans values to zero in the later years. We then transform this adjusted version of regtrans into a binary variable that equals one if any change (pro- or anti-democratic) started in a given year, and zero otherwise. We call this new variable transition, binary. This variable tells us whether a transition has started and allows us to test whether riots have a short-run impact on democratic change, but gives us no information about the direction or magnitude of the change. ${ }^{12}$ We address this limitation by using a count version of transition, binary which we call transition, count. It takes values in the set $\{-$ $2,-1,0,1,2,3\}$ as coded in the Polity IV database. Positive values denote pro-democratic changes (i.e. towards a higher Polity IV index score) of different magnitudes, while negative values denote anti-democratic changes; zero denotes no change. We also use detailed case study evidence we collected on the 43 regime transitions recorded by the Polity IV database as having taken place in sub-Saharan Africa during our sample period. We use this information to identify those cases in which concessions by the incumbent government played a role in the transition (so that it was not simply the result of a coup or an election), which allows us to restrict our regressions to these cases only. This information was collected primarily from the Encyclopaedia Britannica, supplemented with information from other sources. ${ }^{13}$

Naturally, these measures involve a loss of information, both because they do not 
capture the transition period in full (as they look only at the first year of a transition), and because the magnitude of the change is not captured accurately. To account for this, we use the polity 2 variable from the Polity IV database, which is a version of the Polity IV index that has been corrected to allow for use in time series analysis. However, periods of interregnum are coded as zero, which would lead us to mistakenly interpret instances in which a country with a negative polity2 score falls into interregnum (and so its polity2 score increases to 0) as democratic improvements. We avoid this problem by following Brückner and Ciccone (2011) and setting polity2 equal to missing in all interregnum years and years immediately following an interregnum.

The data on riots is from the Social Conflict in Africa Database version 2.0, updated on July 12, 2011 (Hendrix and Idean, 2011). This is a comprehensive database of protests, riots, strikes and other social disturbances in Africa from 1990 to 2010, and it is constructed from Lexis-Nexis searches. ${ }^{14}$ The riots data include geographic coordinates, which we use to construct Map $1 .{ }^{15}$ We include all riots, regardless of whether they eventually led to a civil war. ${ }^{16}$ We create the variable riots to capture the intensity of the protests; it is calculated by adding the duration (in days) of all riots that happened in a given year and in a given country. Different riots are counted individually even if they occurred on the same day. This coding has the advantage that both riots that last more days and days with more riots contribute more to the total. $^{17}$

[Map 1: Riots in Africa, 1990-2007]

We use rainfall data from the Global Precipitation Climatology Project (GPCP) to identify countries and years with droughts between 1990 and 2007. ${ }^{18}$ We say that a country experienced a drought in a given year if its annual rainfall level was below the 20th percentile. We create a binary variable drought that equals one in countryyears where rainfall fell below this threshold, and zero otherwise. ${ }^{19}$ This is our main instrumental variable for riots. 
Our measure of growth in per capita income, which we refer to as gdp per capita growth, is calculated using data on GDP per capita from the World Development Indicators (2011). Deaton and Miller (1995) and Deaton (1999) show that decreases in commodity prices lead to slower (or negative) GDP growth in Africa. Brückner and Ciccone (2010) use monthly commodity price data for 19 commodities to calculate an annual price, and then use information in Deaton (1999) and the UN Commodity Trade Statistics Database to construct a commodity exports basket for each country. This then allows them to construct a country-specific index. ${ }^{20}$ We follow them and use a growth version of this index, which we call commodity price index growth, as an instrument for gdp per capita growth in some of our specifications. ${ }^{2122}$

Figure 1 presents preliminary evidence of the relationship between riots and democratic change. Year 0 is defined as the year in which a transition begins (as recorded by transition, binary) and the axis to the left (right) of that point measures the time before (after) the start of the transition. The $y$-axis records the average across countries of the log of riots in that year. The graph clearly shows that riots increase in the run-up to a transition, and that once a transition has begun the average number of riots declines considerably.

[Figure 1: Pre- and post-transition riot activity]

\section{Empirical Specification}

Our main empirical specification is:

$$
\text { transition }_{i, t}=\alpha+\beta \ln (\text { riots })_{i, t-1}+\gamma \ln (\text { gdp per capita growth })_{i, t-1}+\iota_{i}+\theta_{t}+u_{i, t},
$$

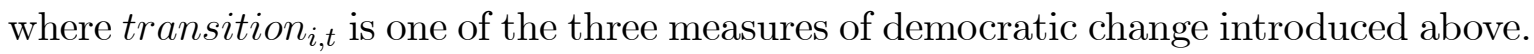
We lag riots and gdp per capita growth by one year because it is unlikely that their effect on democratic change is immediate. ${ }^{23}$ We include country $\left(\iota_{i}\right)$ and year $\left(\theta_{t}\right)$ effects, and 
we also include a lagged dependent variable in the specifications with polity2 as the dependent variable. This partial adjustment model allows us to estimate the short-run and long-run impact of riots on democratic change in a more flexible way. ${ }^{24}$

We include gdp per capita growth in our regressions for three reasons. First, it is likely that fluctuations in recorded national income capture changes in the opportunity cost of a regime challenge, and so they might directly lead to preemptive democratization. This is the idea behind the specifications used by Brückner and Ciccone (2011). Second, including gdp per capita growth is necessary for drought to satisfy the exclusion restriction as an instrumental variable for riots. If riots remains statistically significant in specifications that hold gdp per capita growth constant, then riots caused by drought affect democratic change through channels other than gdp per capita growth (e.g. through shocks to the informal sector, migration, etc.). Finally, including gdp per capita growth allows us to rule out that shocks lead to democratic change because they limit an autocrat's ability to use public funds to "buy off" opposition groups (Haggard and Kaufman, 1997), or because they create opportunities for peaceful constitutional exchange unrelated to the threat of conflict (Congleton, 2007, 2011).

The main problem associated with the estimation of equation (1) is that riots and gdp per capita growth are likely to be endogenous, as a large number of factors, some of them unobservable, might impact on these variables and democratic change. To be able to make a causal claim we must instrument for riots and gdp per capita growth, and we do so by using drought and commodity price index growth as instruments. For drought to be a relevant instrument it needs to be strongly correlated with riots, and we later show that this is the case. To be valid, it must satisfy the independence condition and the exclusion restriction. The independence condition requires that the "treatment" assignment not be determined by the outcome. In our case, whether there is a drought cannot be a function of whether institutional change is about to take place (or not). Since drought (and rain more generally) is not determined by human activities or decisions, at least in the short-run, this condition is satisfied. The exclusion restriction requires that the instrument not belong in the structural equation (1). Specifically, this 
means that drought should not affect democratic change through channels other than riots once we have controlled for country fixed effects, time effects, and gdp per capita growth. Analogously, for commodity price index growth to satisfy the independence condition it must be that political change does not trigger changes in this index; in other words, that it does not affect the growth of international commodity prices. This is true since the countries in our dataset are small players in international markets. The exclusion restriction requires that commodity price index growth only affects democratic change through its impact on gdp per capita growth (once we control for riots), which seems likely to be the case for small commodity exporters.

\section{$5 \quad$ Main Empirical Results}

We present our results in four tables. Table 1 shows OLS and conditional logit estimates of the structural equation (1), as well as estimates of the reduced form where we associate the instrument directly with our measures of democratic change. Table 2 shows the main results from the instrumental variables estimation. Table 3 presents the results when we only consider transitions that involved concessions. Table 4 presents the results for a dynamic panel specification.

\subsection{Benchmark Estimates}

As a benchmark, section A of Table 1 reports OLS and conditional logit estimates of the structural equation (1). The outcome variable in column 1 is transition, binary, and we find that a one standard deviation increase in the log of riots leads to an increase in transition, binary of $0.024 .^{25}$ The mean value of this variable across countries and time is 0.057 , so this is a substantial effect. In column 2, the outcome variable is transition, count, which makes a distinction between transitions to and away from democracy. The results are similar, and we conclude that riots are positively correlated with the likelihood of short-run democratic change. Column 3 shows a specification with polity2 
in levels and a lagged dependent variable; the coefficient estimate on riots is positive but not significant. ${ }^{26}$ Finally, column 4 shows the results from a fixed effects conditional logit estimation with transition, binary as the outcome variable. The coefficient on riots is positive but not significant. ${ }^{27}$ All these correlations are consistent with the hypothesis that riots trigger democratic change. ${ }^{28}$

[Table 1: Structural and Reduced Form Regressions]

\subsection{Reduced Form Estimates}

As we noted above, endogeneity is a serious concern, and so the OLS (and logit) estimates cannot be given a causal interpretation. Before we report the instrumental variables estimates we present evidence on the reduced form, where we regress the measures of democratic change directly on drought. ${ }^{29}$ This gives us an indication of whether the causal relationship we have hypothesized is present. Column 1 in section B of Table 1 reports on the specification with transition, binary as the outcome variable and we find a positive and significant relationship with drought. Column 2 shows that drought is also significant in the regression using transition, count as the measure of democratic change. Column 3 reports the results for the partial adjustment model with polity2; drought is not significantly correlated with polity2, but the sign is as expected.

\subsection{Estimates}

In columns 1 and 2 of Table 2 we present results where we instrument for riots using drought. In section $\mathrm{B}$ of the table we report the first stage results where we regress riots on drought. In both columns drought at time $t-2$ has a significant impact on riots at time $t-1$. Section A of the table presents the second stage results using the 2SLS estimator. The outcome variables are transition, binary and transition, count (the results for polity2 are shown in Table 4). Since the F-statistics are below 10, we use weak-instrument robust inference p-values (in square brackets) to assess significance. 
The point estimate on riots is positive and statistically significant in both columns 1 and 2. Taking the point estimates from column 1, a drought leads to an increase of 0.380 in the log of riots, while a one unit increase in the log of riots leads to an increase of 0.440 in the probability of a transition. It then follows that a drought leads to an increase of $0.440 \times 0.380=0.167$, or 16.7 percentage points, in the probability of a transition. Since the average transition, binary value is 0.057 , this is a considerable increase. The outcome variable in column 2 is transition, count, and again we find a positive and significant effect of riots on democratic change. The estimated coefficients are large, but this is not due to the relative weakness of the drought instrument; since the specifications are just-identified, the 2SLS estimate is median-unbiased (see Angrist and Pischke, 2009, p. 213).

[Table 2: 2SLS, Riots and Democratic Change]

It is plausible that the impact of riots on democratic change is heterogeneous across countries. In this case, the instrumental variable estimate corresponds to an average causal response, and should be interpreted as the impact on democratic change of riots that happen because a country has switched into a state of drought. In other words, the coefficient on riots captures the average democratic change that follows from riots that were triggered by drought. For example, the estimate in column 1 tells us that a drought at time $t-2$ increases the $\log$ of riots at time $t-1$ by 0.380 , so that there is an increase of 16.7 percentage points in the probability of democratic change.

The average causal response is often uninformative because it is instrument-specific and captures only the impact on "compliers" whose treatment status changes as a result of a change in the instrument (Heckman, 1997). In our case, however, the average causal response allows us to establish that the democratic change we observe is a consequence of the increase in riots that resulted from a drought. This proves particularly useful because it isolates the impact that comes from a change in drought status, allowing us to show that a specific shock, drought, can lead to an improvement in democracy because it increases the threat of social conflict, as captured by riots. 
For our interpretation of the estimated IV coefficients as average causal responses to be valid, the monotonicity condition must hold (see Imbens and Angrist, 1994; Angrist and Imbens, 1995). This condition states that the impact of drought on the intensity of riots must always be in the same direction, i.e. riots cannot become less intense because there is a drought (relative to the counterfactual intensity of riots in the case of no drought). In essence, we need to rule out the possibility that droughts inhibit riots. This assumption cannot be tested, but we view it as being fairly uncontroversial.

In columns 3 and 4 of Table 2 we present IV results using drought and the commodities price index growth as instruments for riots and gdp per capita growth. Section B of the table shows the first stage for riots, while Section C shows the first stage for $g d p$ per capita growth. Section A presents the second stage results using the 2SLS estimator. The F-statistics are again below 10, and so we use weak-instrument robust inference p-values (in square brackets) to assess significance. Looking at the top row in column 3 , we observe that the point estimate on riots in the specification with transition, binary is positive and statistically significant (according to two of the three p-values). The outcome variable in column 4 is transition, count, and again we find a large positive effect of riots on democratic change, although it is no longer significant.

In Table 3 we repeat the regressions from Table 2 but we set transition, binary and transition, count to 0 in instances where the transition did not involve concessions by the incumbent. In short, transitions triggered by coups/revolutions or elections are not recorded as democratic changes in these specifications. If the results in Table 2 had been driven by transitions that were due to coups/revolutions or elections, then these results would not show up in Table 3. However, the results are very similar to those in Table 2; if anything, those in Table 3 are stronger. This shows that our results are indeed consistent with the "window of opportunity" hypothesis: riots lead to democractic change because they induce democratic concessions by the incumbent government. ${ }^{30}$

[Table 3: 2SLS, Riots and Democratic Change, Concessions Only] 


\subsection{The Partial Adjustment Model}

Table 4 reports the results for the partial adjustment specification with polity2 as the dependent variable. We include a lagged dependent variable, which introduces what is known as the Nickell bias (see Nickell, 1981). We address this problem by using the Arellano-Bond GMM estimator (Arellano and Bond, 1991). ${ }^{31}$ Column 1 reports the results from a specification where we use drought and lagged right-hand side variables as instruments for the differenced equation. We find the coefficient on riots not to be significant. ${ }^{32}$ In column 2 we repeat these regressions but treat gdp per capita growth as endogenous and include the commodity price index growth as an additional instrument in the Arellano-Bond estimation procedure. The coefficient on riots is significant at the $10 \%$ level.

[Table 4: Dynamic Specification with Polity2]

The Arellano-Bond GMM estimator is intended for cases in which $n$ (i.e. countries) is large and $t$ (i.e. years) is small. However, our panel has at most 41 countries and 18 years, so that the Arellano-Bond estimates could be severely biased. An alternative is to use the bias-corrected least-squares dummy variable (LSDV) estimator (see Bruno, 2005), which performs better than the Arellano-Bond GMM estimator when the number of cross-sectional units is small. The LSDV results are presented in column 3. The point estimate is somewhat smaller than with Arellano-Bond, and significant at the 10 percent level. Focusing on the point estimate obtained with the LSDV estimator, a one standard deviation increase in the log of riots leads to a short-run increase of $1.744 \times 0.131=0.229$ points in the polity2 score, while the long-run impact is considerably larger and equal to 1.16 points. ${ }^{33}$

\subsection{Discussion of the Results}

Taken together, our results suggest that riots trigger democratic change, providing new evidence for the causal mechanism that underlies Acemoglu and Robinson's (2000, 
2001, 2006) theory of political transitions: adverse economic shocks generate social unrest and riots, which in turn lead incumbent governments to make democratic concessions. Moreover, the size of the effect is large and of economic and political importance.

Acemoglu and Robinson's (2000, 2001, 2006) theory of political transitions acknowledges that incumbents might use strategies other than concessions to avoid being overthrown. ${ }^{34}$ For example, they may invest in repression or offer temporary transfers to those who pose a threat to their rule, thus eliminating their incentive to participate in a revolt. ${ }^{35}$ In our setting, food subsidies could be used to mitigate the incentive to riot in the face of a drought, while international food aid could unintentionally serve the same function. It is not possible for us to control for these alternative strategies, and so they remain as potential sources of statistical bias in the estimation of $\beta$ in equation (1). To establish the direction of this bias, let us consider the consequences of omitting spending on repression from equation (1). ${ }^{36}$ The theory predicts that repression is negatively correlated with democratic change and positively correlated with riots. Consequently, failing to control for repression biases the estimate of $\beta$ towards zero, which would work against us finding a coefficient that is significantly different from zero. This means that our estimate of the effect of riots on democratic change should be viewed as a lower bound on the true causal effect.

A related issue is that rain might discourage or stop riots; for example, travel may become more difficult and people may dislike getting wet. One might then think that drought is correlated with riots not because economic conditions provide a reason to protest, but because the lack of rain makes riots possible (given some other underlying cause for the riots). However, this is unlikely to be a problem at an annual level of aggregation. Even in years with heavy rainfall, there will be periods without rain; riots could happen in those periods even if rain, in general, deters riots. 


\section{Conclusions}

This paper has shown that riots triggered by drought lead to democratic change. In doing so, it provides new evidence that conflict can lead to institutional change. While most work in this area has focused on international wars and their impact on institutional change over long periods of time, we have shown that low intensity conflict can also lead to change in relatively short periods of time.

We have shown that droughts increase riots, which in turn lead to more democratic institutions. These results are driven by cases in which democratic concessions were made as a result of riots, and so they support the theory of democratic change formulated by Acemoglu and Robinson (2000, 2001, 2006). Although our focus on the recent experience of sub-Saharan Africa is somewhat specific, our study adds to a growing literature that finds evidence in support of this theory: Aidt and Jensen (2011) find evidence of this mechanism when they look at the international diffusion of information about revolutionary events in Europe in the period 1820-1938; Aidt and Franck (2014) establish a link between local riots and support for the Great Reform Act of 1832 in Britain; Przeworski (2009) studies the correlation between franchise extensions and the "threat of revolution" in a large sample of countries. Overall, this body of work provides compelling evidence in support of the central mechanism in Acemoglu and Robinson's $(2000,2001,2006)$ theory of political transitions, as many episodes of democratic change, both today and in the past, are the result of concessions made by governing elites in response to what they perceived to be threats to the established order. 


\section{Notes}

${ }^{1}$ This question has received a considerable amount of attention in political science and political economy, with seminal contributions by Lipset (1959), Moore (1966), and more recently Przeworski et al. (2000), Rueschemeyer et al. (1992), Boix (2003), Acemoglu and Robinson (2006), and Congleton (2011).

${ }^{2}$ We focus on droughts (large negative rainfall shocks) rather than on rainfall levels because we expect a link between rainfall and riots only in years of drought; that is, the relationship between rain and riots is highly non-linear. For example, we do not expect that a rainfall shock that reduces the rainfall level from above to just below the median will trigger riots, as agricultural production would only be marginally affected. Riots and social unrest are triggered by large negative shocks that seriously disrupt agricultural production.

${ }^{3}$ In the context of the 1974 revolution in Ethiopia, Berhanu (1998, p. 82) explains that "the progressive deterioration of the quality of life for many Ethiopians was aggravated by a major droughtinduced famine (1973-74) that killed hundreds of thousands. This increased the unpopularity of the regime..." Similarly, Appiah and Gates (2010, p. 234) explain the causes of the 1974 revolt against Diori in Niger by arguing that "Diori managed to maintain order until the devastating drought reached its peak in 1973. Popular unrest escalated into riots when evidence emerged that Diori and members of his administration were enriching themselves with diverted foreign food aid." More recently, referring to the 1990 Sudan famine, de Waal (1997, p. 103) explains that "[f]oreign NGOs planned to distribute food in rural areas: the government wanted to divert it to the towns. In one instance, after a food riot in Um Ruwaba town, NGO relief food intended for displaced Southerners was commandeered at gunpoint and distributed to the town's residents."

${ }^{4}$ Using data from the Encyclopaedia Britannica and other sources, we found that 28 of the 43 large changes in the democracy measure in our sample involved democratic concessions by the incument government.

${ }^{5}$ The work by Berger and Spoerer (2001), however, indicates that there was a strong link between poor economic conditions and the European revolutions of 1848.

${ }^{6}$ Franck (2012) establishes a causal link between short-term variations in local tax income (instrumented by rainfall levels) in 19th century France and electoral support for democratic institutions.

${ }^{7}$ See Ciccone (2011) and Miguel and Satyanath (2011) for a discussion of these results.

${ }^{8}$ There are several other reasons why the window of opportunity may be open in situations where 
riots are widespread, which do not require that the initial riots be directed at regime change. First, an effective regime challenge requires coordination, and riots may serve as a focal point or a public signal that, in the spirit of Ellis and Fender (2011), helps overcome this coordination problem. Second, as stressed by Tullock (1974) and Kuran (1989), revolt requires leadership, and opposition leaders might be able to redirect the dissatisfaction with economic conditions to dissatisfaction with the existing regime. This line of reasoning also makes it clear that preemptive democratic change need not (and often does not) result in voting rights and increased political influence being granted to those who riot. All that is required is for those who might take advantage of the situation or provide leadership for a regime challenge to be granted increased and lasting political rights.

${ }^{9}$ Aidt and Jensen (2011) present a mathematical model of regime transitions in the tradition of Acemoglu and Robinson $(2000,2006)$ that formalizes these predictions and shows the conditions under which revolution can happen on the equilibrium path.

${ }^{10}$ The countries are listed in Table A1 in the online appendix.

${ }^{11} \mathrm{~A}$ major advantage of the Polity IV data is that they are coded in a systematic way for a large number of countries for a long time span. However, it has been noted that they do not capture aspects of democratization related to suffrage reforms very well (Aidt and Eterovic, 2011), and that changes within the middle range of the scale of the Polity IV index are difficult to interpret (Cheibub, Gandhi, Vreeland, 2010).

${ }^{12}$ We note that of 43 regime changes observed in the data, 7 were anti-democratic and 36 were prodemocratic. Hence, we feel it is reasonable to think of this binary variable as a measure of democratic change. We decided against dropping instances of anti-democratic change because that would have introduced a selection problem.

${ }^{13}$ More details on the coding can be found in the online appendix.

${ }^{14}$ These involved searching for each country name and the codewords "protest" or "strike" or "riot" or "violence" or "attack" in the following wire services: Agence France Presse - English, The Associated Press, Associated Press Online, and Associated Press Worldstream. The articles were then inspected to determine the type of incident they referred to and to avoid double-counting. For more details, see www.scaddata.org.

${ }^{15}$ All GIS data uses the world equidistant-cylindrical projection.

${ }^{16}$ We exclude 75 riots which are recorded as being part of an ongoing civil war. The original number of riots in the dataset is 7,337 , so that we are left with a net total of 7,262 .

${ }^{17}$ There are a total of 7,262 events in the dataset (after excluding events that are part of an ongoing 
civil war), of which only 67 ended in a year different from their start year. In these cases we allocated them to the year in which they started.

${ }^{18}$ To ensure consistency with previous work, we draw on data from Ciccone (2011) and Miguel and Satyanath (2011).

${ }^{19}$ Benson and Clay (1998) propose several different definitions of drought. We follow Brückner and Ciccone (2010) and adopt a physical (rather than economic) definition. We use a 20th percentile threshold, so that the country-years with the $20 \%$ lowest rainfall levels will be considered to be experiencing a drought. The results are similar if we use a 15th percentile threshold.

${ }^{20}$ They calculate the price index for country $c$ in year $t$ as follows:

$$
\operatorname{index}_{c t}=\sum_{i=1}^{19} \omega_{c i} P_{i t}
$$

where $\omega_{c i}$ is the export share of commodity $i$ (assumed to be fixed over time) and $P_{i t}$ is its price. For more details, see Brückner and Ciccone (2010).

${ }^{21}$ We are grateful to Markus Brückner and Antonio Ciccone for making their data available to us.

${ }^{22}$ Table A2 in the online appendix shows the summary statistics for the main variables.

${ }^{23}$ Our results are robust to using contemporaneous growth in GDP per capita, as suggested by Barron, Miguel and Satyanath (2013), and to using growth in GDP per capita lagged twice. See Table A3 in the online appendix for the details.

${ }^{24}$ This introduces what is known as Nickell bias (Nickell, 1981); we return to this issue when we discuss our results.

${ }^{25}$ Table A2 in the online appendix shows that the standard deviation is 1.744 , so $1.744 \times 0.014=$ 0.024

${ }^{26}$ The difference in the number of observations in columns 2 and 3 is due to differences in how Burke and Leigh (2010) and Brückner and Ciccone (2011) deal with years in which a country was in interregnum. Burke and Leigh (2010) set the transition variable to 0, while Brückner and Ciccone (2011) set the polity2 variable to missing.

${ }^{27}$ We lose some observations because conditional logit estimation uses only countries with variation in the transitions, binary variable (i.e. that experience both years with a transition and years without a transition) during the sample period.

${ }^{28}$ We report estimates using GDP data from the World Development Indicators (2011).

${ }^{29}$ We include drought lagged twice. This is because we use variables dated t-2 to instrument for 
riots at $\mathrm{t}-1$, which is the variable that appears in equation (1).

${ }^{30}$ In the online appendix we present a number of results where we allow riots to have a different impact on democratic change depending on whether they happen in urban or rural areas. We find no large differences in the impact different types of riots have on democratic change.

${ }^{31}$ We adopt the Arellano-Bond GMM estimator instead of the system estimator because it involves fewer internal instruments.

${ }^{32}$ The Arellano-Bond test for AR(1) errors rejects the null hypothesis of no autocorrelation, while the test for $\operatorname{AR}(2)$ errors does not reject the null. Moreover, the Hansen test does not reject the null hypothesis of valid instruments.

${ }^{33}$ In the long-run, polity2 reaches a steady-state, i.e. polity $\mathscr{2}_{t}=$ polity $\mathscr{2}_{t-1}$, and so the long-run effect is $\frac{0.229}{1-0.803}=1.162$ (on a scale from -10 to 10$)$.

${ }^{34}$ It is also possible, as suggested in Aidt and Albornoz (2011), that foreign governments might induce or encourage regime transitions in the wake of adverse economic shocks.

${ }^{35}$ The drawback of this strategy is that it is only credible when the "threat of revolution" is perceived to be real. For this reason, it is often insufficient to avoid a regime challenge, and the incumbent must then resort to either democratic reform or repression.

${ }^{36}$ The logic with regards to omitted food subsidies and international food aid is the same.

\section{References}

[1] Acemoglu, Daron and James A. Robinson, 2000. "Why Did the West Extend the Franchise? Democracy, Inequality, and Growth in Historical Perspective." Quarterly Journal of Economics 115(4), 1167-1199.

[2] Acemoglu, Daron and James A. Robinson, 2001. "A Theory of Political Transition." American Economic Review 91, 938-963.

[3] Acemoglu, Daron and James A. Robinson, 2006. Economic origins of dictatorship and democracy. Cambridge University Press, UK.

[4] Aidt, Toke S. and Peter S. Jensen, 2011. "Workers of the World, Unite! Franchise Extensions and the Threat of Revolution in Europe, 1820-1938." Cambridge Working Papers in Economic 1102.

[5] Aidt, Toke S. and Dalibor S. Eterovic, 2011. "Political Competition, Electoral Participation and Public Finance in 20th Century Latin America." European Journal of Political Economy 27(1), 181-200. 
[6] Aidt, Toke S. and Facundo Albornoz, 2011. "Political Regimes and Foreign Intervention." Journal of Development Economics 94, 192-201.

[7] Aidt, Toke S. and Raphaël Franck, 2014. "Democratization Under the Threat of Revolution: Evidence from the Great Reform Act of 1832." Unpublished working paper, University of Cambridge.

[8] Andrews, Josephine and Robert W. Jackson. 2005. "Strategic Fools: Electoral Rule Choice under Extreme Uncertainty." Electoral Studies 24, 65-84.

[9] Angrist, Joshua and Guido Imbens, 1995. "Two-Stage Least Squares Estimation of Average Causal Effects in Models with Variable Treatment Intensity." Journal of the American Statistical Association 90, 430: 431-442.

[10] Angrist, Joshua and Jörn-Steffen Pischke, 2009. Mostly Harmless Econometrics: An Empiricist's Companion. Princeton University Press, Princeton, NJ.

[11] Appiah, Kwame Anthony and Henry Louis Gates, Jr., 2010. Encyclopedia of Africa. Oxford University Press, Oxford, UK.

[12] Arellano, Manuel and Stephen Bond, 1991. "Some tests of Specification for Panel Data: Monte Carlo Evidence and an Application to Employment Equations." Review of Economic Studies 58: 277-297.

[13] Barron, Manuel, Edward Miguel and Shanker Satyanath. 2013. "Economic Shocks and Democratization in Africa". Political Science Research and Methods. doi:10.1017/psrm.2013.27

[14] Benson, Charlotte and Edward Clay, 1998. "The Impact of Drought on SubSaharan African Economies: A Preliminary Examination." World Bank Technical Papers 401, The World Bank, Washington D.C.

[15] Berger, Helge and Spoerer, Mark, 2001. "Economic Crisis and the European Revolutions of 1848." Journal of Economic History 61(2), 293-326.

[16] Berhanu, Kassahun, 1998. "Democracy, State-Building, and "Nations" in Ethiopia: 1974-95," in Democratization in Late Twentieth-Century Africa, ed. Jean-Germain Gros, Greenwood Press, Westport, CT.

[17] Besley, Timothy and Torsten Persson, 2008. "Wars and State Capacity." Journal of the European Economic Association 2, 522-530.

[18] Besley, Timothy and Torsten Persson, 2009. "The Origins of State Capacity: Property Rights, Taxation, and Politics." American Economic Review 99: 1218-1244.

[19] Besley, Timothy and Torsten Persson, 2010. "State Capacity, Conflict, and Development." Econometrica 78: 1-34. 
[20] Besley, Timothy and Torsten Persson, 2011. Pillars of Prosperity. Princeton University Press, Princeton, NJ.

[21] Boix, Carles, 2003. Democracy and redistribution. Cambridge University Press, Cambridge, UK.

[22] Bruno, Giovanni S.F., 2005. "Approximating the Bias of the LSDV Estimator for Dynamic Unbalanced Panel Data Models." Economics Letters 87, 361-366.

[23] Brückner, Markus and Antonio Ciccone, 2011. "Rain and the Democratic Window of Opportunity." Econometrica 79(3), 923-947.

[24] Brückner, Markus and Antonio Ciccone, 2010. "International Commodity Price Shocks, Growth, and the Outbreak of Civil War in Sub-Saharan Africa." Economic Journal 120, 519-534.

[25] Burke, Paul and Andrew Leigh, 2010. "Do Output Contractions Trigger Democratic Change?" American Economic Journal: Macroeconomics 2, 124-157.

[26] Cheibub, Jose Antonio, Jennifer Gandhi, and James Raymond Vreeland, 2010. "Democracy and Dictatorship Revisited." Public Choice 143, 67-101.

[27] Ciccone, Antonio, 2011. "Economic Shocks and Civil Conflict: A Comment." American Economic Journal: Applied Economics 3, 215-227.

[28] Collier, Paul and Anke Hoeffler. 1998. "On Economic Causes of Civil War." Oxford Economic Papers 50(4), 563-73.

[29] Collier, Paul and Anke Hoeffler. 2004. "Greed and Grievance in Civil War." Oxford Economic Papers 56(4), 563-95.

[30] Congleton, Roger D., 2007. "From Royal to Parliamentary Rule Without Revolution: The Economics of Constitutional Exchange Within Divided Governments." European Journal of Political Economy 23(2), 261-284.

[31] Congleton, Roger D., 2011. Perfecting parliament. Cambridge University Press, Cambridge, UK.

[32] Deaton, Angus, 1999. "Commodity Prices and Growth in Africa." The Journal of Economic Perspectives 13(3), 23-40.

[33] Deaton, Angus and Ron Miller, 1995. "International Commodity Prices, Macroeconomic Performance, and Politics in sub-Saharan Africa." Princeton Studies in International Finance, No. 79.

[34] de Waal, Alex, 1997. Famine Crimes, African Rights and the International African Institute, London. 
[35] Dincecco, Mark, Giovanni Federico, and Andrea Vindigni, 2011. "Warfare, Taxation, and Political Change: Evidence from the Italian Risorgimento." Journal of Economic History 71: 887-914.

[36] Dincecco, Mark and Mauricio Prado, 2012. "Warfare, Fiscal Capacity, and Performance." Journal of Economic Growth 17: 171-203.

[37] Ellis, Christopher J. and John Fender, 2011. "Information Cascades and Revolutionary Regime Transition." Economic Journal 121(551), 763-792.

[38] Franck, Raphaël, 2012. "The Political Consequences of Income Shocks: Explaining the Consolidation of Democracy in France." Unpublished working paper. Department of Economics, Bar-Ilan University.

[39] Haggard, Stephan and Kaufman, Robert R. 1997. "The Political Economy of Democratic Transitions." Comparative Politics, 93(2), 118-25.

[40] Heckman, James, 1997. "Instrumental Variables: A Study of Implicit Behavioral Assumptions Used in Making Program Evaluations." Journal of Human Resources $32,441-462$.

[41] Hendrix, Cullen S. and Idean Salehyan, 2011. "Social Conflict in Africa Database (SCAD)." www.scaddata.org, Version 2.0.

[42] Hoffman, Philip and Jean-Laurent Rosenthal, 1997. "The Political Economy of Warfare and Taxation in Early Modern Europe: Historical Lessons for Economic Development." In J. Drobak \& J. Nye (Eds.), The Frontiers of the New Institutional Economics. Academic Press, St Louis, MO.

[43] Imbens, Guido and Joshua Angrist, 1994. "Identification and Estimation of Local Average Treatment Effects." Econometrica 62, 467-475.

[44] Jensen, Peter Sandholt and Kristian Skrede Gleditsch. 2009. "Rain, Growth, and Civil War: The Importance of Location." Defence and Peace Economics 20(5), $359-72$.

[45] Kuran, Timur, 1989. "Sparks and Prairie Fires: A Theory of Unanticipated Political Revolution." Public Choice 61, 41-74.

[46] Lipset, Seymour Martin, 1959. "Some Social Requisites of Democracy: Economic Development and Political Legitimacy." American Political Science Review 53, 69-105.

[47] Marshall, M., and K. Jaggers, 2005. "Polity IV Project: Dataset Users' Manual," Center for Global Policy, George Mason University. Available at www.cidcm.umd.edu/polity. [Polity IV Data Computer File, Version p4v2004, 
Center for International Development and Conflict Management, University of Maryland, College Park, MD.]

[48] Meredith, Michael, 2005. The State of Africa: A History of Fifty Years of Independence. Simon \& Schuster, London, UK.

[49] Miguel, Edward, Shanker Satyanath, and Ernest Sergenti. 2004. "Economic Shocks and Civil Conflict: An Instrumental Variables Approach." Journal of Political Economy 112(41), 725-53.

[50] Miguel, Edward and Shanker Satyanath, 2011. "Re-examining Economics and Civil Conflict." American Economic Journal: Applied Economics 3, 228-232.

[51] Moore, Barrington, 1966. The Social Origins of Dictatorship and Democracy. Beacon Press, Boston, MA.

[52] Nickell, Steven J., 1981. "Biases in Dynamic Models with Fixed Effects." Econometrica 49, 1417-1426.

[53] O'Brien, Patrick, 2011. "The Contributions of Warfare with Revolutionary and Napoleonic France to the Consolidation and Progress of the British Industrial Revolution." Working paper 150/11, London School of Economics.

[54] Piot, Charles, 2010. Nostalgia for the Future: West Africa after the Cold War. The University of Chicago Press, Chicago, IL.

[55] Przeworski, Adam, Michael E. Alvarez, Jose A. Cheibub, and Fernando Limongi, 2000. Democracy and development: political institutions and well-being in the world, 1950-1990. Cambridge University Press, Cambridge, UK.

[56] Przeworski, Adam, 2009. "Conquered or Granted? A History of Suffrage Extensions." British Journal of Political Science 39, 291-321.

[57] Rueschemeyer, Dietrich, Evelyne Huber Stephens, and John D. Stephens, 1992. Capitalist Development and Democracy. University of Chicago Press, Chicago.

[58] Tilly, Charles (1990), Coercion, Capital and European States, AD 990-1992, Blackwells.

[59] Tullock, Gordon, 1974. The social dilemma. The economics of war and revolution. Center for the Study of Public Choice, Blacksburg, VA.

[60] Walton, John and David Seddon, 1994. Free Markets and Food Riots: The Politics of Global Adjustment. Wiley-Blackwell.

[61] World Bank, 2011, World Development Indicators. The World Bank, Washington DC. 
Map 1: Riots in Africa, 1990-2007

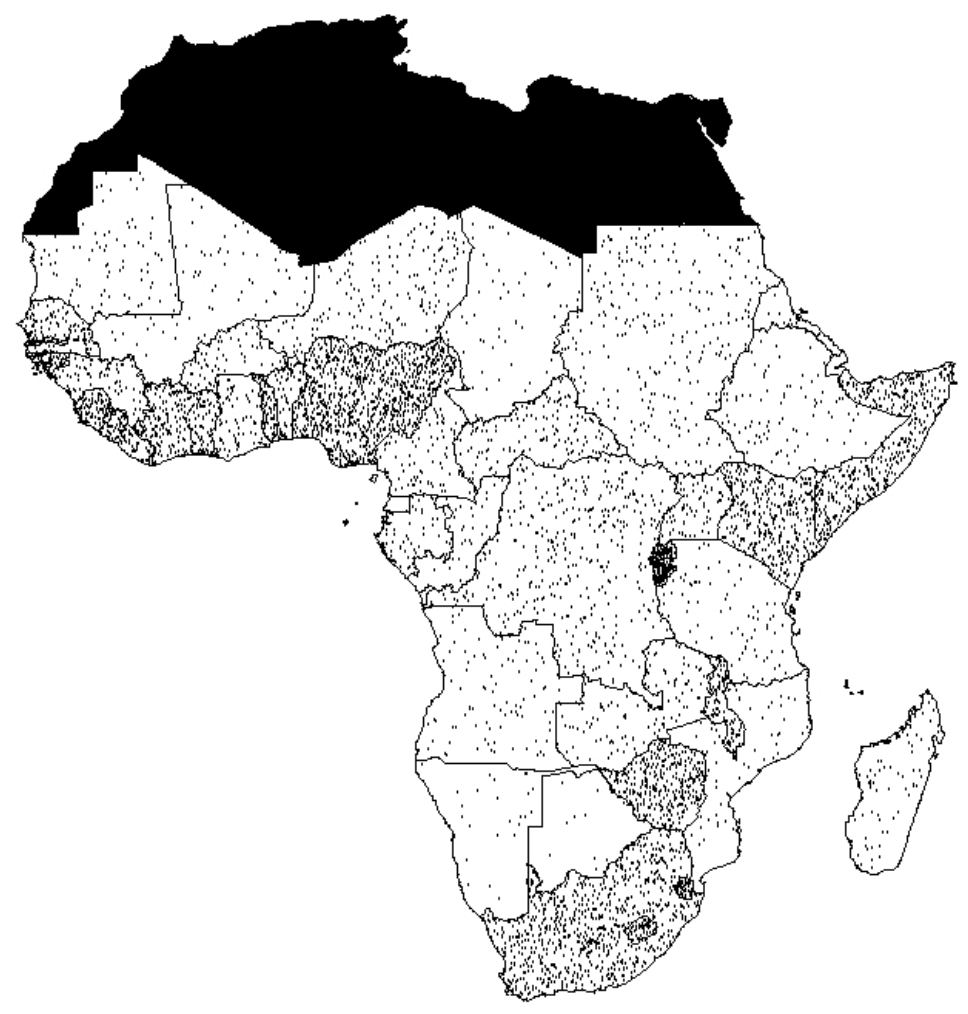

Figure 1: Pre-transition riot activity

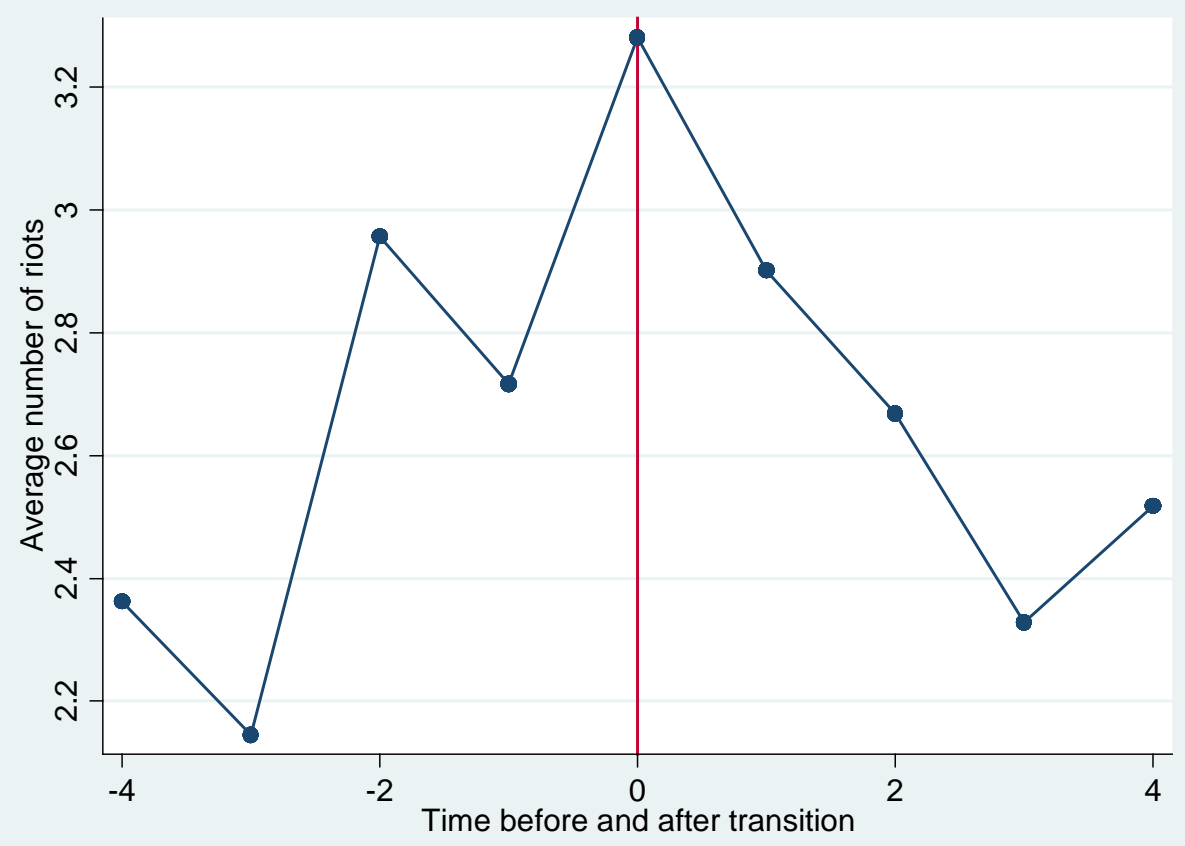

Notes: Average number of riots is the log of riots averaged across the countries in the sample. Transition, binary is used to identify when $t=0$. The number of observations is not the same in all years. 
Table 1: Structural and Reduced Form Regressions

(A) Structural Regressions: Riots and Democratic Change

\begin{tabular}{lcccc}
\hline & \multicolumn{1}{c}{$(1)$} & $(2)$ & $(3)$ & $(4)$ \\
\cline { 2 - 5 } & $\begin{array}{c}\text { Transition, } \\
\text { binary }_{\mathrm{t}}\end{array}$ & $\begin{array}{c}\text { Transition, } \\
\text { count }\end{array}$ & Polity2 $_{\mathrm{t}}$ & $\begin{array}{c}\text { Transition, } \\
\text { binary }_{\mathrm{t}}\end{array}$ \\
\cline { 2 - 5 } & OLS & OLS & OLS & $\begin{array}{c}\text { Conditional } \\
\text { Logit }\end{array}$ \\
\cline { 2 - 5 } Riots $_{\mathrm{t}-1}$, logs & $0.014^{\dagger}$ & $0.036^{* *}$ & 0.117 & 0.260 \\
GDP per capita growth & $(0.007)$ & $(0.015)$ & $(0.076)$ & $(0.162)$ \\
Polity2 & -0.111 & 0.239 & 2.453 & -2.709 \\
Country fixed effects & $(0.132)$ & $(0.373)$ & $(1.567)$ & $(4.012)$ \\
Year effects & & & $0.710^{* * *}$ & \\
Observations & $\mathrm{Y}$ & $\mathrm{Y}$ & $(0.032)$ & $\mathrm{Y}$ \\
& & $\mathrm{Y}$ & $\mathrm{Y}$ & $\mathrm{Y}$ \\
\hline \hline
\end{tabular}

(B) Reduced Form: Drought and Democratic Change

(1) (2)

(3)

Transition, $\quad$ Transition, $\quad$ Polity2 $_{\mathrm{t}}$

\begin{tabular}{ccc} 
binary $_{\mathrm{t}}$ & count $_{\mathrm{t}}$ & \\
\hline OLS & OLS & OLS \\
\hline $0.159^{* * *}$ & $0.339^{* *}$ & 0.599 \\
$(0.056)$ & $(0.149)$ & $(0.511)$
\end{tabular}

Instrument:

Drought $_{\mathrm{t}-2}$

$(0.149)$

Controls:

GDP per capita growth t-1 $_{1}$

0.121

2.434

Polity $2_{\mathrm{t}-1}$

(0.376)

(1.753)

$0.713^{* * *}$

(0.033)

Country fixed effects

Year effects

$\mathrm{Y}$
$\mathrm{Y}$

$\mathrm{Y}$

$\mathrm{Y}$

Observations

640

641

605

Notes: † significance at the $10 \%$ level, $* *$ at the $5 \%$ level, $* * *$ at the $1 \%$ level. Standard errors are clustered by country and reported in parentheses. Column 4 in section (A) reports conditional logit coefficients. 
Table 2: 2SLS, Riots and Democratic Change

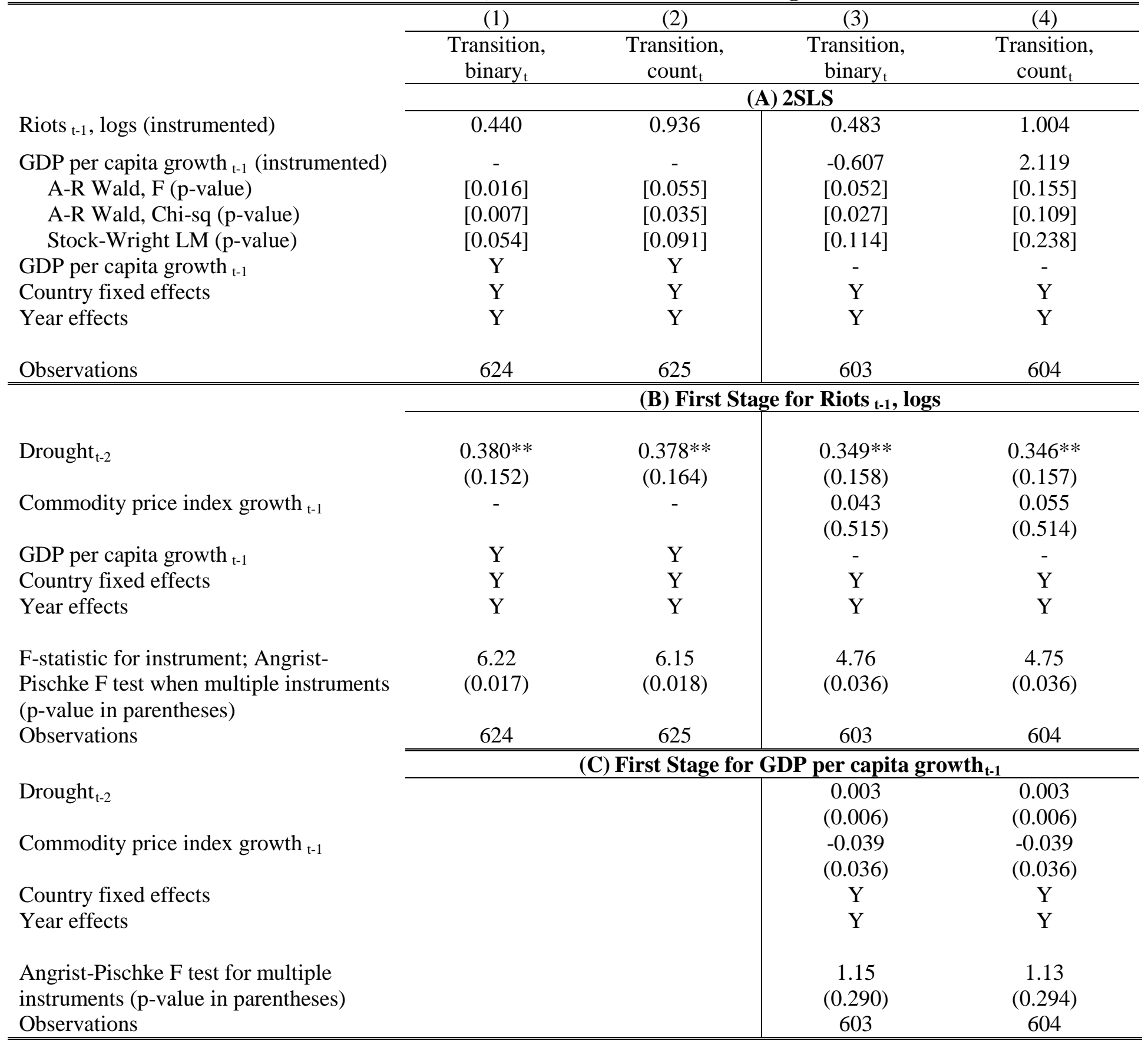

Notes: In part (A) we report p-values for three significance tests in brackets; these are tests of the significance of the endogenous regressor(s) in the structural equation, where the null is that it equals (they jointly equal) zero and that the over-identifying restrictions (where relevant) are valid. These tests are robust to weak instruments, and the versions we implement are robust to both heteroskedasticity and within-country correlation in the errors. In parts (B) and (C) standard errors are clustered and reported in parentheses (); † indicates significance at the $10 \%$ level, ** at the 5\% level, *** at the $1 \%$ level. 
Table 3: 2SLS, Riots and Democratic Change, Concessions Only

\begin{tabular}{|c|c|c|c|c|}
\hline & $(1)$ & $(2)$ & (3) & $(4)$ \\
\hline & $\begin{array}{c}\text { Transition, } \\
\text { binary }_{t}\end{array}$ & $\begin{array}{c}\text { Transition, } \\
\text { count }_{t}\end{array}$ & $\begin{array}{c}\text { Transition, } \\
\text { binary }_{t}\end{array}$ & $\begin{array}{c}\text { Transition, } \\
\text { count }_{t}\end{array}$ \\
\hline & \multicolumn{4}{|c|}{ (A) 2SLS } \\
\hline Riots $_{\mathrm{t}-1}$, logs (instrumented) & 0.399 & 0.942 & 0.435 & 1.021 \\
\hline $\begin{array}{l}\text { GDP per capita growth } \\
\text { (instrumented) }\end{array}$ & - & - & -0.169 & 0.187 \\
\hline A-R Wald, F (p-value) & [0.026] & [0.057] & [0.082] & [0.135] \\
\hline A-R Wald, Chi-sq (p-value) & {$[0.014]$} & {$[0.037]$} & [0.048] & [0.092] \\
\hline Stock-Wright LM (p-value) & {$[0.074]$} & [0.093] & {$[0.175]$} & {$[0.200]$} \\
\hline GDP per capita growth $_{\mathrm{t}-1}$ & $\mathrm{Y}$ & $\mathrm{Y}$ & - & - \\
\hline Country fixed effects & $\mathrm{Y}$ & $\mathrm{Y}$ & $\mathrm{Y}$ & $\mathrm{Y}$ \\
\hline Year effects & $\mathrm{Y}$ & $\mathrm{Y}$ & $\mathrm{Y}$ & $\mathrm{Y}$ \\
\hline \multirow[t]{2}{*}{ Observations } & 624 & 625 & 603 & 604 \\
\hline & \multicolumn{4}{|c|}{ (B) First Stage for Riots ${ }_{t-1}$, logs } \\
\hline Drought $_{\mathrm{t}-2}$ & $\begin{array}{c}0.380^{* *} \\
(0.152)\end{array}$ & $\begin{array}{c}0.378 * * \\
(0.152)\end{array}$ & $\begin{array}{c}0.349 * * \\
(0.158)\end{array}$ & $\begin{array}{c}0.346 * * \\
(0.157)\end{array}$ \\
\hline Commodity price index growth $\mathrm{t}-1$ & - & - & $\begin{array}{c}0.043 \\
(0.515)\end{array}$ & $\begin{array}{c}0.055 \\
(0.514)\end{array}$ \\
\hline GDP per capita growth ${ }_{t-1}$ & Y & Y & - & - \\
\hline Country fixed effects & Y & $\mathrm{Y}$ & $\mathrm{Y}$ & Y \\
\hline Year effects & $\mathrm{Y}$ & $\mathrm{Y}$ & $\mathrm{Y}$ & $\mathrm{Y}$ \\
\hline $\begin{array}{l}\text { F-statistic for instrument; Angrist- } \\
\text { Pischke F test when multiple } \\
\text { instruments (p-value in parentheses) }\end{array}$ & $\begin{array}{c}6.22 \\
(0.017)\end{array}$ & $\begin{array}{c}6.15 \\
(0.018)\end{array}$ & $\begin{array}{c}4.76 \\
(0.036)\end{array}$ & $\begin{array}{c}4.75 \\
(0.036)\end{array}$ \\
\hline \multirow[t]{2}{*}{ Observations } & 624 & 625 & 603 & 604 \\
\hline & \multicolumn{4}{|c|}{ (C) First Stage for GDP per capita growth ${ }_{t-1}$} \\
\hline Drought $_{\mathrm{t}-2}$ & & & $\begin{array}{c}0.003 \\
(0.006)\end{array}$ & $\begin{array}{c}0.003 \\
(0.006)\end{array}$ \\
\hline Commodity price index growth ${ }_{\mathrm{t}-1}$ & & & $\begin{array}{l}-0.039 \\
(0.036)\end{array}$ & $\begin{array}{l}-0.039 \\
(0.036)\end{array}$ \\
\hline Country fixed effects & & & $\mathrm{Y}$ & $\mathrm{Y}$ \\
\hline Year effects & & & $\mathrm{Y}$ & $\mathrm{Y}$ \\
\hline $\begin{array}{l}\text { Angrist-Pischke F test for multiple } \\
\text { instruments (p-value in parentheses) } \\
\text { Observations }\end{array}$ & & & $\begin{array}{c}1.15 \\
(0.290) \\
603\end{array}$ & $\begin{array}{c}1.13 \\
(0.204) \\
604\end{array}$ \\
\hline
\end{tabular}

Notes: In this table we only consider transitions where concessions were made by the incumbent; in all other cases the dependent variable is set equal to 0 . In part (A) we report p-values for three significance tests in brackets; these are tests of the significance of the endogenous regressor(s) in the structural equation, where the null is that it equals (they jointly equal) zero and that the over-identifying restrictions (where relevant) are valid. These tests are robust to weak instruments, and the versions we implement are robust to both heteroskedasticity and within-country correlation in the errors. In parts (B) and (C) standard errors are clustered and reported in parentheses (); $†$ indicates significance at the $10 \%$ level, ** at the $5 \%$ level, $* * *$ at the $1 \%$ level. 
Table 4: Dynamic Specification with Polity2

\begin{tabular}{|c|c|c|c|}
\hline & (1) & $(2)$ & (3) \\
\hline & Polity $2_{t}$ & Polity $2_{t}$ & Polity $2_{t}$ \\
\hline & Arellano-Bond GMM & Arellano-Bond GMM & LSDV \\
\hline Riots $_{\mathrm{t}-1}$, logs & $\begin{array}{c}0.329 \\
(0.236)\end{array}$ & $\begin{array}{c}0.492^{\dagger} \\
(0.292)\end{array}$ & $\begin{array}{c}0.131^{\dagger} \\
(0.067)\end{array}$ \\
\hline GDP per capita growth ${ }_{t-1}$ & $\begin{array}{c}3.513 \\
(2.477)\end{array}$ & $\begin{array}{c}21.668 \\
(15.938)\end{array}$ & $\begin{array}{c}2.851 \\
(1.828)\end{array}$ \\
\hline Polity $2_{\mathrm{t}-1}$ & $\begin{array}{c}0.916 * * * \\
(0.089)\end{array}$ & $\begin{array}{c}0.975 * * * \\
(0.114)\end{array}$ & $\begin{array}{c}0.803^{* * * *} \\
(0.036)\end{array}$ \\
\hline Country fixed effect & $\mathrm{Y}$ & $\mathrm{Y}$ & $\mathrm{Y}$ \\
\hline Year effect & $\mathrm{Y}$ & $\mathrm{Y}$ & $\mathrm{Y}$ \\
\hline Arellano-Bond AR(1) test, $\mathrm{p}$-value & 0.000 & 0.001 & 0.000 \\
\hline Arellano-Bond AR(2) test, $\mathrm{p}$-value & 0.826 & 0.649 & 0.812 \\
\hline Excluded Instrument(s): & Drought $_{\mathrm{t}-2}$ & $\begin{array}{l}\text { Drought }_{\mathrm{t}-2} \\
\text { Commodity price index } \\
\text { growth }_{\mathrm{t}-1}\end{array}$ & - \\
\hline Sargan overid test, p-value & - & - & 0.990 \\
\hline Hansen overid test, p-value & 0.983 & 0.571 & - \\
\hline Observations & 546 & 529 & 546 \\
\hline \multicolumn{4}{|c|}{$\begin{array}{l}\text { Notes: } \dagger \text { significance at the } 10 \% \text { level, } * * \text { at the } 5 \% \text { level, } * * * \text { at the } 1 \% \text { level. The standard errors in the Arellano-Bond specification } \\
\text { are consistent in the presence of any pattern of heteroskedasticity and autocorrelation. The Arellano-Bond result is based on using one } \\
\text { lag in levels as instruments. The Arellano-Bond (1991) tests for autocorrelation test the null hypothesis of no first and second order } \\
\text { serial autocorrelation in the errors against the alternative of AR(1) and AR(2), respectively. LSDV standard errors are bootstrapped with } \\
100 \text { repetitions (but the coefficient on riots stays significant with 10, } 20 \text { and } 50 \text { repetitions). The LSDV estimation uses Arellano-Bond } \\
\text { and not system GMM. }\end{array}$} \\
\hline
\end{tabular}




\title{
Online Appendix
}

\section{The Democratic Window of Opportunity: Evidence}

\section{from Riots in sub-Saharan Africa}

\author{
Toke S. Aidt* \\ Gabriel Leon ${ }^{\dagger}$ \\ University of Cambridge \\ University of Cambridge
}

June 24, 2014

\section{Political transition variables}

We use the Polity IV database to construct three different and complementary measures of political change. The Polity IV database contains a number of different indicators of political authority, and is built around the polity IV index. This index codes three key aspects of a country's political system: i) competitiveness and openness in the process of executive recruitment, ii) constraints on the chief executive, and iii) competitiveness and regulation of political participation. A weighted sum of the components is used to construct two summary variables, measuring democracy on a scale of 0 to 10 (the

\footnotetext{
${ }^{*}$ Faculty of Economics and Jesus College, University of Cambridge, Cambridge CB3 9DD, United Kingdom. E-mail: toke.aidt@econ.cam.ac.uk. Phone: +44 1223 335231; and CESifo Munich.

${ }^{\dagger}$ Faculty of Economics and St Catharine's College, University of Cambridge, Cambridge CB3 9DD, United Kingdom. E-mail: gj138@cam.ac.uk.
} 
DEMOC score) and autocracy on a scale of -10 to 0 (the AUTOC score). The polity $I V$ index is the sum of these two sub-indexes.

We use this database to construct three different measures of democratic change. Our first two variables, transition, binary and transition, count, are based on the regtrans variable. The Polity IV manual (p.35) defines regtrans as follows: "The Polity has undergone a substantive regime transition between period $t-1$ and $t$, defined as a 'regime change'. A 'regime change' is defined simply as a three-point change in either the polity's DEMOC or AUTOC score." A score of +3 corresponds to a "major democratic transition" defined as an increase of six points or more in the Polity IV score over a period of three years or less, including a shift from an autocratic Polity IV value $(-10$ to 0$)$ to a partial democratic Polity IV value $(+1$ to +6$)$ or to a full democratic Polity IV value $(+7$ to +10$)$; or a shift from a partial democratic value to a full democratic value. A score of +2 corresponds to a "minor regime change", defined as a three to five point increase in the Polity IV index over a period of three years or less, including a shift from autocratic to partial democratic. A score of +1 corresponds to a "positive regime change", defined as an increase of three or more points in the Polity IV score without a shift in regime type, as defined for scores of +2 and +3 . A score of -1 corresponds to a "negative regime change", defined as a 3 to 5 point drop in the Polity IV index. A score of -2 corresponds to an "adverse regime transition", defined as a six or more point decrease in the Polity IV index, or a collapse of central state authority or a revolutionary transformation in the mode of governance (not a democratic transition). We also use the polity 2 variable, which is a version of the Polity IV index that has been corrected to allow for use in time series analysis. 


\section{Urban Riots}

\subsection{Baseline}

In our paper we argue that riots threaten the incumbent regime, which may then respond by making democratic concessions. Urban riots are often viewed as a much more serious threat to the government than rural riots, and so we check whether our results are robust to focusing only on that type of riot. If our results go away, then this would raise some doubts regarding the interepretation of our results. To determine which riots happen in urban areas, we use the GIS map " $1 \mathrm{~km} 2010$ Africa population distribution" from Afripop, which is a digital map with 1 square kilometer cells that record the population in that area. These data are shown in Map A1. Using our GIS riots data, we can then assign a population value to each riot, which we then turn into a binary variable where an area is considered to be urban if the population is more than 100 individuals per square kilometer.

[Map A1: Population Density in Africa, 2010]

Our results are presented in Table A4. We find that the coefficient on urban riots in column 1 is similar to those in column 3 in Table 2, and that the endogenous variables are jointly significant according to two of the three p-values reported. The results in column 2 are also similar to those in column 4 in Table 2. In Table A5 we run the Arellano-Bond GMM and the LSDV, and the coefficients are positive, although not significant.

[Table A4: 2SLS, Urban Riots]

[Table A5: Dynamic Specification, Urban Riots] 
However, it is unclear where the boundary between urban and rural should lie, and in fact it is likely that such discrete labelling is not appropriate. To address this issue we re-estimate our specification using three different weighted riots measures, where more weight is given to riots that happen in more populated areas, closer to the capital city, or in countries where the population is more concentrated around the capital.

\section{$2.2 \quad$ Weighted Riots Results}

We first create a riot measure where riots are given weights that depend on the population of the location in which they occur. As a result, riots that happen in more urbanized areas carry a larger weight. We again use the GIS map " $1 \mathrm{~km} 2010$ Africa population distribution" from Afripop, and assign a population density to each riot, with the log of population density becoming their weight. ${ }^{1}$

Table A6 shows the results for the 2SLS. The middle of the table shows the first stage results for riots weighted by population density, where the F-stat is quite low; the bottom of the table shows the first stage for GDP per capita growth. The top of the table presents the results for the 2SLS: when using the binary variable, the coefficient is 0.594 , which is similar to what we found before, and significant according to two of the three p-values. The second column, which looks at the count variable, has a large coefficient. Table A7 presents the results for the dynamic specification using polity2, where little changes relative to Table 4 in the paper.

[Table A6: Riots weighted by Population Density]

[Table A7: Dynamics]

However, riots in and near the capital city may be more threatening to the regime

\footnotetext{
${ }^{1}$ We use logs because population density is highly skewed, with a few cities (e.g., Lagos) having very large values.
} 
than riots further away, even if some of these regions are heavily populated. To consider this issue we create a new weighted riots variable, where the weights are now given by the inverse of the log distance between the location of the riots and the capital city of the country in which they happen. Riots that happen closer to the capital city receive a larger weight. Data for the location of the capital cities are from the CShapes dataset (Wedmann, Kuse and Gleditsch, 2010). Table A8 presents the results: although the first stage results are quite similar, the coefficients on the second stage are twice as large. Table A9 presents the results for the dynamic specification using polity2, where the coefficients are twice as large as those in Table A7.

[Table A8: Riots weighted by Distance to Capital City]

[Table A9: Dynamics]

Finally, Do and Campante (2009) argue that the concentration of population around the capital city can act as a substitute for governance institutions, providing checks on the behavior of (autocratic) rulers. $^{2}$ The theory is that population concentration in and around the capital makes it easier for opposition groups to channel popular unrest into a regime challenge. Building on this logic, we conjecture that riots represent a greater threat in countries where people live closer to the center of power. To capture this empirically, we create a weighted riots measure where the weight is equal to the gravity-based measure of population concentration around the capital city, centrality, constructed by Campante and Do (2010). ${ }^{3}$ The results are presented in Tables A10

\footnotetext{
${ }^{2}$ To substantiate this claim, Do and Campante (2009) report a positive association between population concentration near the capital city and better governance and more redistribution.

${ }^{3}$ Campante and Do (2010) construct two centered indices of spatial concentration, $P C I_{1}$ and $P C I_{2}$. We use $\mathrm{PCI}_{2}$, which is normalized by population size and the maximum distance within each country. Using $P C I_{1}$ instead does not change our qualitative results. The index is available for 1990, 1995 and 2000, but shows little within country variation over time, so we use the index value in 1990 in the estimations.
} 
and A11, and are similar to those when riots are weighted by their distance to the capital (Tables A8 and A9).

[Table A10: Riots weighted by Centrality]

[Table A11: Dynamics]

\section{References}

[1] Do, Quoc-Anh and Filipe Campante, 2009. "Keeping Dictators Honest: The Role of Population". Research Collection, School of Economics, Paper 1135.

[2] Campante, Filipe and Quoc-Anh Do, 2010. "A Centered Index of Spatial Concentration: Expected Influence Approach and Application to Population and Capital Cities". Unpublished manuscript.

[3] Weidmann, Nils B., Doreen Kuse and Kristian Skrede Gleditsch. 2010. "The Geography of the International System: TheCShapes Dataset." International Interactions 36(1). 


\section{ONLINE APPENDIX}

\section{Table A1: Countries in Dataset}

\begin{tabular}{ccc}
\hline \hline Angola & Ghana & Nigeria \\
Benin & Guinea & Rwanda \\
Botswana & Guinea-Bissau & Senegal \\
Burkina Faso & Ivory Coast & Sierra Leone \\
Burundi & Kenya & Somalia \\
Central African Rep & Lesotho & South Africa \\
Cameroon & Liberia & Sudan \\
Chad & Madagascar & Swaziland \\
Republic of Congo & Malawi & Togo \\
DR Congo & Mali & Tanzania \\
Djibouti & Mauritania & Uganda \\
Ethiopia & Mozambique & Zambia \\
Gabon & Namibia & Zimbabwe \\
The Gambia & Niger & \\
& & \\
\hline \hline
\end{tabular}

Table A2: Summary Statistics

\begin{tabular}{|c|c|c|c|c|c|}
\hline & Mean & Standard Deviation & Min. & Max. & Observations \\
\hline Transition, binary & 0.057 & 0.232 & 0 & 1 & 757 \\
\hline Transition, count & 0.083 & 0.531 & -2 & 3 & 758 \\
\hline Polity2 & -0.476 & 5.616 & -10 & 9 & 712 \\
\hline Riots, logs & 2.509 & 1.744 & 0 & 7.249 & 700 \\
\hline Drought & 0.199 & 0.400 & 0 & 1 & 758 \\
\hline GDP per capita growth & 0.005 & 0.063 & -0.699 & 0.316 & 680 \\
\hline Commodity price index growth & 0.023 & 0.175 & -0.382 & 0.744 & 637 \\
\hline \multicolumn{6}{|c|}{$\begin{array}{l}\text { Notes: Transition, binary refers to a modified version of the regtrans variable in the Polity IV database, and it equals one if a political } \\
\text { change was initiated in that year (as captured by regtrans), and zero otherwise. Transition, count takes an integer value between -2 and } 3 \text { and } \\
\text { captures the direction and size of the transition, but only in its first year. Riots are calculated by adding up the duration (in days) of all riots } \\
\text { that happened in a given year; different riots are counted individually even if they occurred on the same day. Drought is a dummy variable } \\
\text { equal to one if the average rainfall in the year was in the bottom quintile of the rain distribution for Sub-Saharan Africa. GDP per capita } \\
\text { growth is calculated using data from the World Development Indicators (2011), while commodity price index growth is from Brückner and } \\
\text { Ciccone (2010) and is calculated using country-specific baskets of exported commodities. We include data from } 1989 \text { for the variables for } \\
\text { which they are available (i.e., not for riots). }\end{array}$} \\
\hline
\end{tabular}


Table A3: Robustness to using different lags of GDP per capita growth

\begin{tabular}{|c|c|c|c|c|}
\hline & (1) & (2) & (3) & (4) \\
\hline & $\begin{array}{c}\text { Transition, } \\
\text { binary }_{t}\end{array}$ & $\begin{array}{c}\text { Transition, } \\
\text { count }_{t}\end{array}$ & $\begin{array}{c}\text { Transition, } \\
\text { binary }_{t}\end{array}$ & $\begin{array}{c}\text { Transition, } \\
\text { count }_{t}\end{array}$ \\
\hline & All & All & Only Concessions & Only Concessions \\
\hline & \multicolumn{4}{|c|}{$\begin{array}{l}\text { (A) Robustness to using GDP per capita growth at } t \\
\text { 2SLS }\end{array}$} \\
\hline Riots $_{\mathrm{t}-1}$, logs (instrumented) & 0.440 & 0.935 & 0.399 & 0.942 \\
\hline A-R Wald, F (p-val) & [0.016] & [0.054] & [0.026] & {$[0.057]$} \\
\hline A-R Wald, Chi-sq (p-val) & {$[0.007]$} & {$[0.035]$} & {$[0.014]$} & {$[0.037]$} \\
\hline Stock-Wright LM (p-val) & {$[0.054]$} & [0.091] & {$[0.074]$} & {$[0.093]$} \\
\hline GDP p/cap growth & $\mathrm{Y}$ & $\mathrm{Y}$ & $\mathrm{Y}$ & $\mathrm{Y}$ \\
\hline Country Fixed Effects & $\mathrm{Y}$ & $\mathrm{Y}$ & $\mathrm{Y}$ & $\mathrm{Y}$ \\
\hline Year Effects & $\mathrm{Y}$ & $\mathrm{Y}$ & $\mathrm{Y}$ & $\mathrm{Y}$ \\
\hline \multirow[t]{2}{*}{ Observations } & 624 & 625 & 624 & 625 \\
\hline & \multicolumn{4}{|c|}{ First Stage for Riots $_{t-1}$, logs } \\
\hline Drought $_{\mathrm{t}-2}$ & $0.380 * *$ & $0.377 * *$ & $0.380 * *$ & $0.377 * *$ \\
\hline GDP p/cap t growth & $\mathrm{Y}$ & $\mathrm{Y}$ & $\mathrm{Y}$ & $\mathrm{Y}$ \\
\hline Country Fixed Effects & $\mathrm{Y}$ & $\mathrm{Y}$ & $\mathrm{Y}$ & $\mathrm{Y}$ \\
\hline Year Effects & $\mathrm{Y}$ & $\mathrm{Y}$ & $\mathrm{Y}$ & $\mathrm{Y}$ \\
\hline F statistic for instrument & 6.13 & 6.06 & 6.13 & 6.06 \\
\hline (p-val in parentheses) & $(0.018)$ & $(0.019)$ & $(0.018)$ & $(0.019)$ \\
\hline \multirow[t]{2}{*}{ Observations } & 624 & 625 & 624 & 625 \\
\hline & \multicolumn{4}{|c|}{$\begin{array}{c}\text { (B) Robustness to using GDP per capita growth at } t-2 \\
\text { 2SLS }\end{array}$} \\
\hline Riots $_{\mathrm{t}-1}$, logs (instrumented) & 0.391 & 0.811 & 0.360 & 0.834 \\
\hline A-R Wald, F (p-val) & {$[0.052]$} & {$[0.151]$} & {$[0.077]$} & {$[0.143]$} \\
\hline A-R Wald, Chi-sq (p-val) & [0.033] & [0.119] & [0.053] & {$[0.111]$} \\
\hline Stock-Wright LM (p-val) & [0.090] & [0.169] & {$[0.120]$} & [0.163] \\
\hline GDP p/cap ${ }_{t-2}$ growth & $\mathrm{Y}$ & $\mathrm{Y}$ & $\mathrm{Y}$ & $\mathrm{Y}$ \\
\hline Country Fixed Effects & $\mathrm{Y}$ & $\mathrm{Y}$ & $\mathrm{Y}$ & $\mathrm{Y}$ \\
\hline Year Effects & $\mathrm{Y}$ & $\mathrm{Y}$ & $\mathrm{Y}$ & $\mathrm{Y}$ \\
\hline \multirow[t]{2}{*}{ Observations } & 586 & 587 & 586 & 587 \\
\hline & \multicolumn{4}{|c|}{ First Stage for Riots $_{t-1}$, logs } \\
\hline Drought $_{\mathrm{t}-2}$ & $\begin{array}{c}0.353^{\dagger} \\
(0.184)\end{array}$ & $\begin{array}{c}0.350^{\dagger} \\
(0.184)\end{array}$ & $\begin{array}{l}0.353^{\dagger} \\
(0.184)\end{array}$ & $\begin{array}{c}0.350^{\dagger} \\
(0.184)\end{array}$ \\
\hline GDP p/capt-2 growth & $\mathrm{Y}$ & $\mathrm{Y}$ & $\mathrm{Y}$ & $\mathrm{Y}$ \\
\hline Country Fixed Effects & $\mathrm{Y}$ & $\mathrm{Y}$ & $\mathrm{Y}$ & $\mathrm{Y}$ \\
\hline Year Effects & $\mathrm{Y}$ & $\mathrm{Y}$ & $\mathrm{Y}$ & $\mathrm{Y}$ \\
\hline F statistic for instrument & 3.70 & 3.64 & 3.70 & 3.64 \\
\hline (p-val in parentheses) & $(0.062)$ & $(0.064)$ & $(0.062)$ & $(0.064)$ \\
\hline Observations & 586 & 587 & 586 & 587 \\
\hline
\end{tabular}


Map A1: Population Density in Africa, 2010

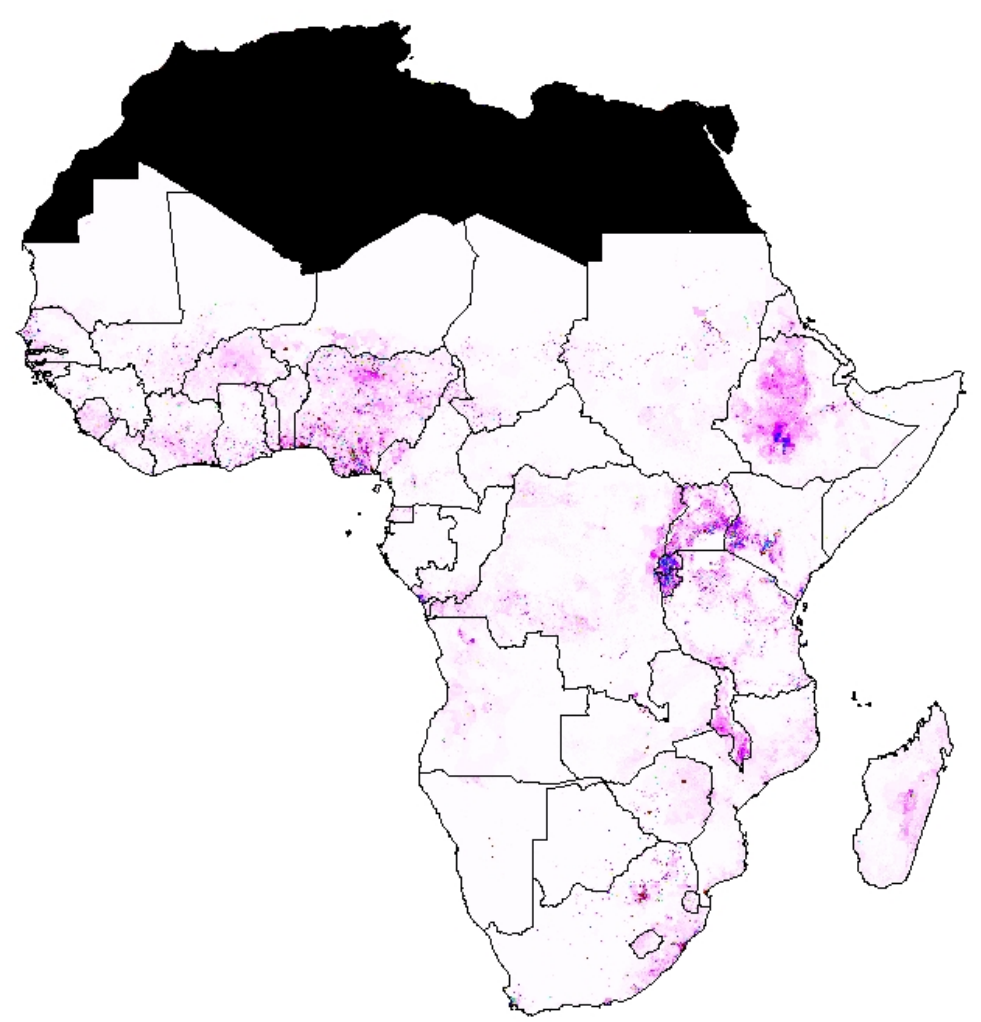


Table A4: 2SLS, Urban Riots

\begin{tabular}{|c|c|c|c|c|}
\hline & (1) & (2) & (3) & (4) \\
\hline & $\begin{array}{c}\text { Transition, } \\
\text { binary }_{t}\end{array}$ & $\begin{array}{c}\text { Transition, } \\
\text { count }_{t}\end{array}$ & $\begin{array}{c}\text { Transition, } \\
\text { binary }_{t}\end{array}$ & $\begin{array}{c}\text { Transition, } \\
\text { count }_{\mathrm{t}}\end{array}$ \\
\hline & All & All & Only Concessions & Only Concessions \\
\hline & \multicolumn{4}{|c|}{ 2SLS } \\
\hline Urban Riots $_{\mathrm{t}-1}$, logs (instrumented) & 0.474 & 0.983 & 0.427 & 1.001 \\
\hline GDP p/cap ${ }_{\mathrm{t}-1}$ growth (instrumented) & 2.209 & 7.806 & 2.367 & 5.975 \\
\hline A-R Wald, F (p-val) & [0.052] & [0.155] & [0.082] & [0.135] \\
\hline A-R Wald, Chi-sq (p-val) & {$[0.027]$} & [0.109] & [0.048] & [0.092] \\
\hline Stock-Wright LM (p-val) & [0.114] & [0.238] & [0.175] & {$[0.200]$} \\
\hline Country Fixed Effects & $\mathrm{Y}$ & $\mathrm{Y}$ & $\mathrm{Y}$ & $\mathrm{Y}$ \\
\hline Year Effects & $\mathrm{Y}$ & $\mathrm{Y}$ & $\mathrm{Y}$ & $\mathrm{Y}$ \\
\hline \multirow[t]{2}{*}{ Observations } & 603 & 604 & 603 & 604 \\
\hline & \multicolumn{4}{|c|}{ First Stage for Urban Riots ${ }_{t-1}$, logs } \\
\hline Drought $_{\mathrm{t}-2}$ & $\begin{array}{c}0.339 \\
(0.211)\end{array}$ & $\begin{array}{c}0.338 \\
(0.211)\end{array}$ & $\begin{array}{c}0.339 \\
(0.211)\end{array}$ & $\begin{array}{c}0.338 \\
(0.211)\end{array}$ \\
\hline Commodity Price Index growth ${ }_{t-1}$ & $\begin{array}{c}.276 \\
(0.423)\end{array}$ & $\begin{array}{c}0.279 \\
(0.424)\end{array}$ & $\begin{array}{c}0.276 \\
(0.423)\end{array}$ & $\begin{array}{c}0.279 \\
(0.424)\end{array}$ \\
\hline Country Fixed Effects & $\mathrm{Y}$ & $\mathrm{Y}$ & $\mathrm{Y}$ & $\mathrm{Y}$ \\
\hline Year Effects & $\mathrm{Y}$ & $\mathrm{Y}$ & $\mathrm{Y}$ & $\mathrm{Y}$ \\
\hline $\begin{array}{l}\text { Angrist-Pischke F test for excluded } \\
\text { instruments (p-val in parentheses) } \\
\text { Observations }\end{array}$ & $\begin{array}{c}2.80 \\
(0.103) \\
603\end{array}$ & $\begin{array}{c}2.78 \\
(0.104) \\
604\end{array}$ & $\begin{array}{c}2.80 \\
(0.103) \\
603\end{array}$ & $\begin{array}{c}2.78 \\
(0.104) \\
604\end{array}$ \\
\hline Observations & \multicolumn{4}{|c|}{ First Stage for GDP p/cap growth ${ }_{t-1}$} \\
\hline Drought $_{\mathrm{t}-2}$ & $\begin{array}{c}.003 \\
(.006)\end{array}$ & $\begin{array}{c}0.003 \\
(0.006)\end{array}$ & $\begin{array}{c}0.003 \\
(0.006)\end{array}$ & $\begin{array}{c}0.003 \\
(0.006)\end{array}$ \\
\hline Commodity Price Index growth ${ }_{t-1}$ & $\begin{array}{l}-.039 \\
(.036)\end{array}$ & $\begin{array}{l}-0.039 \\
(0.036)\end{array}$ & $\begin{array}{c}-0.039 \\
(0.036)\end{array}$ & $\begin{array}{l}-0.039 \\
(0.036)\end{array}$ \\
\hline Country Fixed Effects & $\mathrm{Y}$ & $\mathrm{Y}$ & $\mathrm{Y}$ & $\mathrm{Y}$ \\
\hline Year Effects & $\mathrm{Y}$ & $\mathrm{Y}$ & $\mathrm{Y}$ & $\mathrm{Y}$ \\
\hline $\begin{array}{l}\text { Angrist-Pischke F test for excluded } \\
\text { instruments (p-val in parentheses) } \\
\text { Observations }\end{array}$ & $\begin{array}{l}1.17 \\
(.287) \\
603\end{array}$ & $\begin{array}{c}1.14 \\
(.292) \\
604\end{array}$ & $\begin{array}{c}1.17 \\
(0.287) \\
603\end{array}$ & $\begin{array}{c}1.14 \\
(0.292) \\
604\end{array}$ \\
\hline
\end{tabular}

Notes: $\dagger$ significance at the $10 \%$ level, ${ }^{* *}$ at the $5 \%$ level, $* * *$ at the $1 \%$ level. Clustered standard errors in parentheses (). We report p-values for three significance tests in brackets; these are tests of the joint significance of the endogenous regressors in the structural equation, where the null is that they equal zero and that the over-identifying restrictions (where relevant) are valid. Their primary appeal in our case lies in that they are robust to weak instruments, and the versions we implement are robust to both heteroskedasticity and within-country correlation in the errors. 
Table A5: Dynamic Specification, Urban Riots

\begin{tabular}{|c|c|c|}
\hline & (1) & (2) \\
\hline & Polity $2_{t}$ & Polity2 ${ }_{t}$ \\
\hline & Arellano-Bond GMM & LSDV \\
\hline Urban Riots $_{\mathrm{t}-1}$, logs & $\begin{array}{c}0.707 \\
(0.605)\end{array}$ & $\begin{array}{c}0.053 \\
(0.130)\end{array}$ \\
\hline GDP p/cap growth ${ }_{t-1}$ & $\begin{array}{c}18.872 \\
(13.801)\end{array}$ & $\begin{array}{c}2.625 \\
(1.809)\end{array}$ \\
\hline Polity $2_{\mathrm{t}-1}$ & $\begin{array}{l}1.020 * * * \\
(0.126)\end{array}$ & $\begin{array}{c}0.803 * * * \\
(0.036)\end{array}$ \\
\hline Country Fixed Effect & $\mathrm{Y}$ & $\mathrm{Y}$ \\
\hline Year Effect & $\mathrm{Y}$ & Y \\
\hline Arellano-Bond AR(1) test & p-val: 0.001 & p-val: 0.000 \\
\hline Arellano-Bond AR(2) test & p-val: 0.758 & p-val: 0.797 \\
\hline Excluded Instrument: & $\begin{array}{l}\text { Drought }_{\mathrm{t}-2} \\
\text { Commodity Price Index } \\
\text { growth }_{\mathrm{t}-1}\end{array}$ & \\
\hline Sargan overid test, p-val & - & 0.988 \\
\hline Hansen overid test, p-val & 0.442 & - \\
\hline Observations & 529 & 546 \\
\hline \multicolumn{3}{|c|}{$\begin{array}{l}\text { Notes: } \dagger \text { significance at the } 10 \% \text { level, } * * \text { at the } 5 \% \text { level, } * * * \text { at the } 1 \% \text { level. The standard errors in } \\
\text { the Arellano-Bond specification are consistent in the presence of any pattern of heteroskedasticity } \\
\text { and autocorrelation. The Arellano-Bond result is based on using one lag in levels as instruments. The } \\
\text { Arellano-Bond (1991) tests for autocorrelation test the null hypothesis of no first and second order } \\
\text { serial autocorrelation in the errors against the alternative of AR(1) and AR(2), respectively. LSDV } \\
\text { standard errors are bootstrapped with } 100 \text { repetitions (but the coefficient on riots stays significant } \\
\text { with } 10,20 \text { and } 50 \text { repetitions). The LSDV estimation uses A-B and not system GMM. }\end{array}$} \\
\hline
\end{tabular}




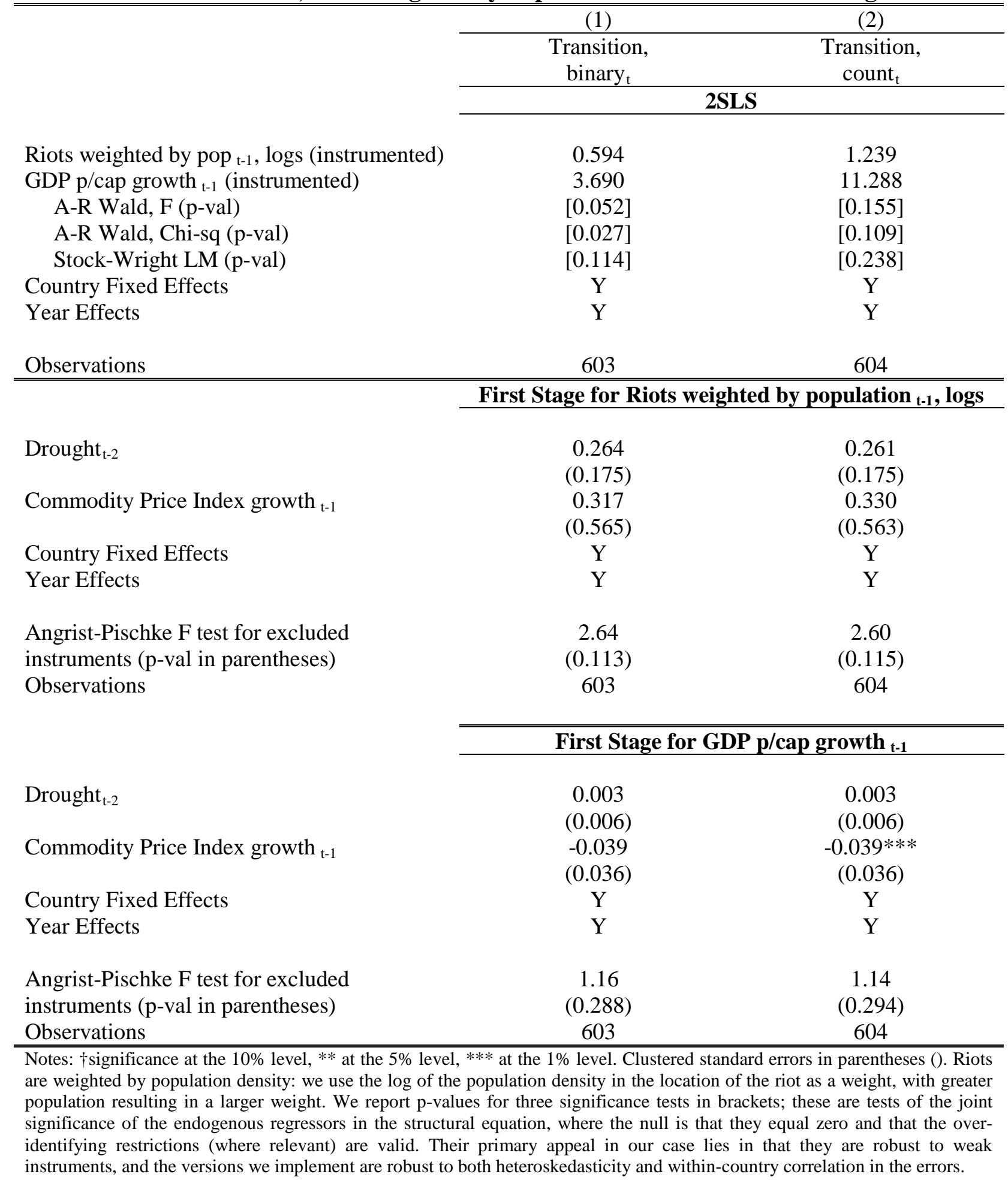


Table A7: Dynamic Specification, Riots weighted by Population and Democratic Change

\begin{tabular}{|c|c|c|}
\hline & (1) & (2) \\
\hline & Polity $2_{t}$ & Polity $2_{t}$ \\
\hline & Arellano-Bond GMM & LSDV \\
\hline Riots $_{\mathrm{t}-1}$, logs & $\begin{array}{l}0.478^{\dagger} \\
(.286)\end{array}$ & $\begin{array}{c}0.128 * * \\
(0.062)\end{array}$ \\
\hline GDP p/cap growth $_{\mathrm{t}-1}$ & $\begin{array}{c}21.362 \\
(15.910)\end{array}$ & $\begin{array}{c}2.823 \\
(1.814)\end{array}$ \\
\hline Polity $2_{\mathrm{t}-1}$ & $\begin{array}{c}0.994 * * * \\
(0.114)\end{array}$ & $\begin{array}{c}0.804^{* * * *} \\
(0.036)\end{array}$ \\
\hline Country Fixed Effect & $\mathrm{Y}$ & Y \\
\hline Year Effect & $\mathrm{Y}$ & $\mathrm{Y}$ \\
\hline Arellano-Bond AR(1) test & p-val: 0.001 & p-val: 0.000 \\
\hline Arellano-Bond AR(2) test & p-val: 0.601 & p-val: 0.797 \\
\hline Excluded Instrument: & $\begin{array}{l}\text { Drought }_{\mathrm{t}-2} \\
\text { Commodity Price Index } \\
\text { growth }_{\mathrm{t}-1}\end{array}$ & \\
\hline Sargan overid test & - & p-val: 0.990 \\
\hline Hansen overid test & p-val: 0.599 & - \\
\hline Observations & 529 & 546 \\
\hline \multicolumn{3}{|c|}{$\begin{array}{l}\text { Notes: †significance at the } 10 \% \text { level, }{ }^{* *} \text { at the } 5 \% \text { level, }{ }^{* * *} \text { at the } 1 \% \text { level. The standard errors in the Arellano- } \\
\text { Bond specification are consistent in the presence of any pattern of heteroskedasticity and autocorrelation. The } \\
\text { Arellano-Bond result is based on using one lag in levels as instruments. The Arellano-Bond (1991) tests for } \\
\text { autocorrelation test the null hypothesis of no first and second order serial autocorrelation in the errors against the } \\
\text { alternative of AR(1) and AR(2), respectively. LSDV standard errors are bootstrapped with } 100 \text { repetitions (but } \\
\text { the coefficient on riots stays significant with 10, } 20 \text { and } 50 \text { repetitions). The LSDV estimation uses A-B and not } \\
\text { system GMM. }\end{array}$} \\
\hline
\end{tabular}


Table A8: 2SLS, Riots weighted by Distance to Capital City and Democratic Change






\section{Table A9: Dynamic Specification, Riots weighted by Distance to Capital City and Democratic Change}

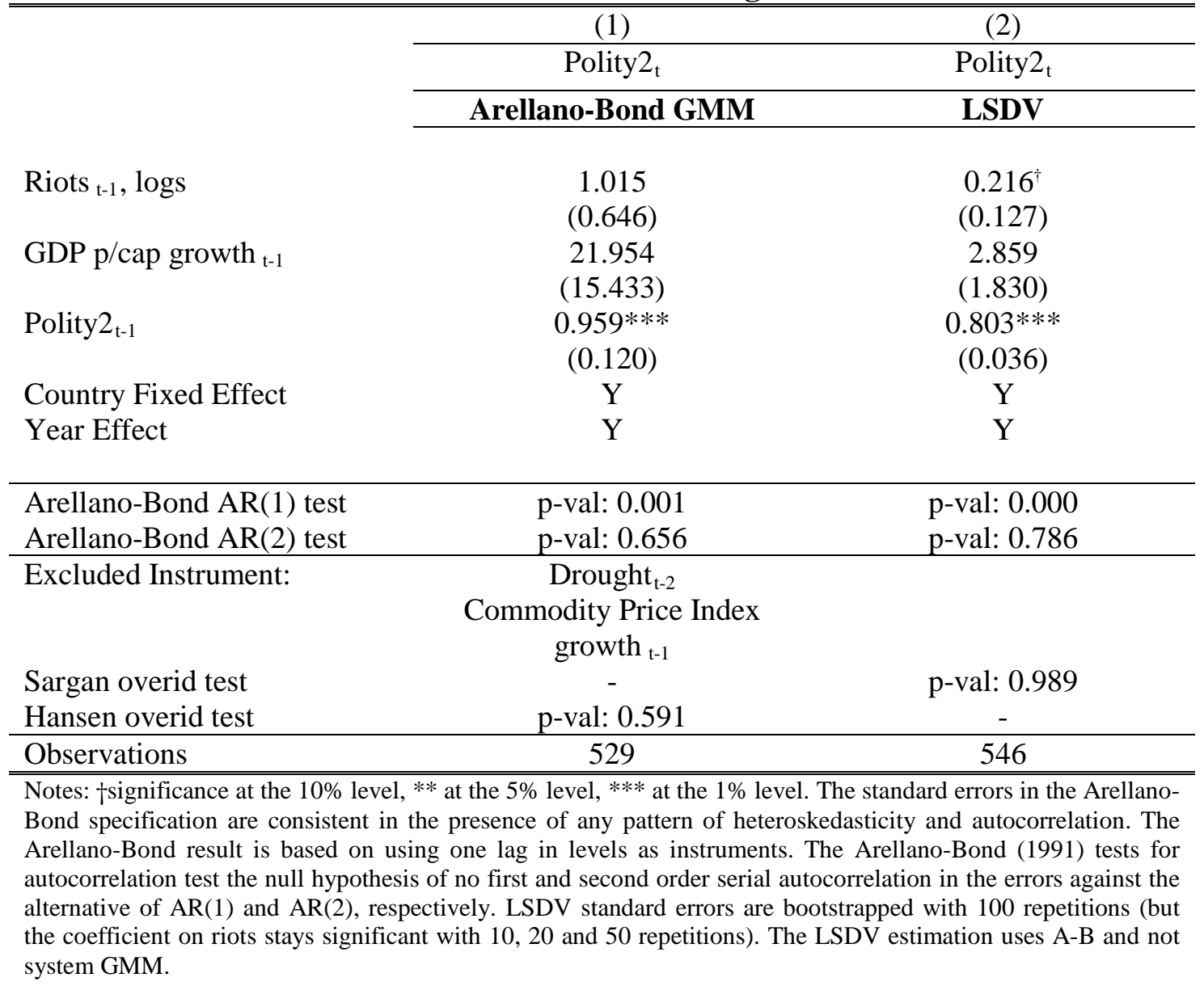


Table A10: 2SLS, Riots weighted by Centrality and Democratic Change

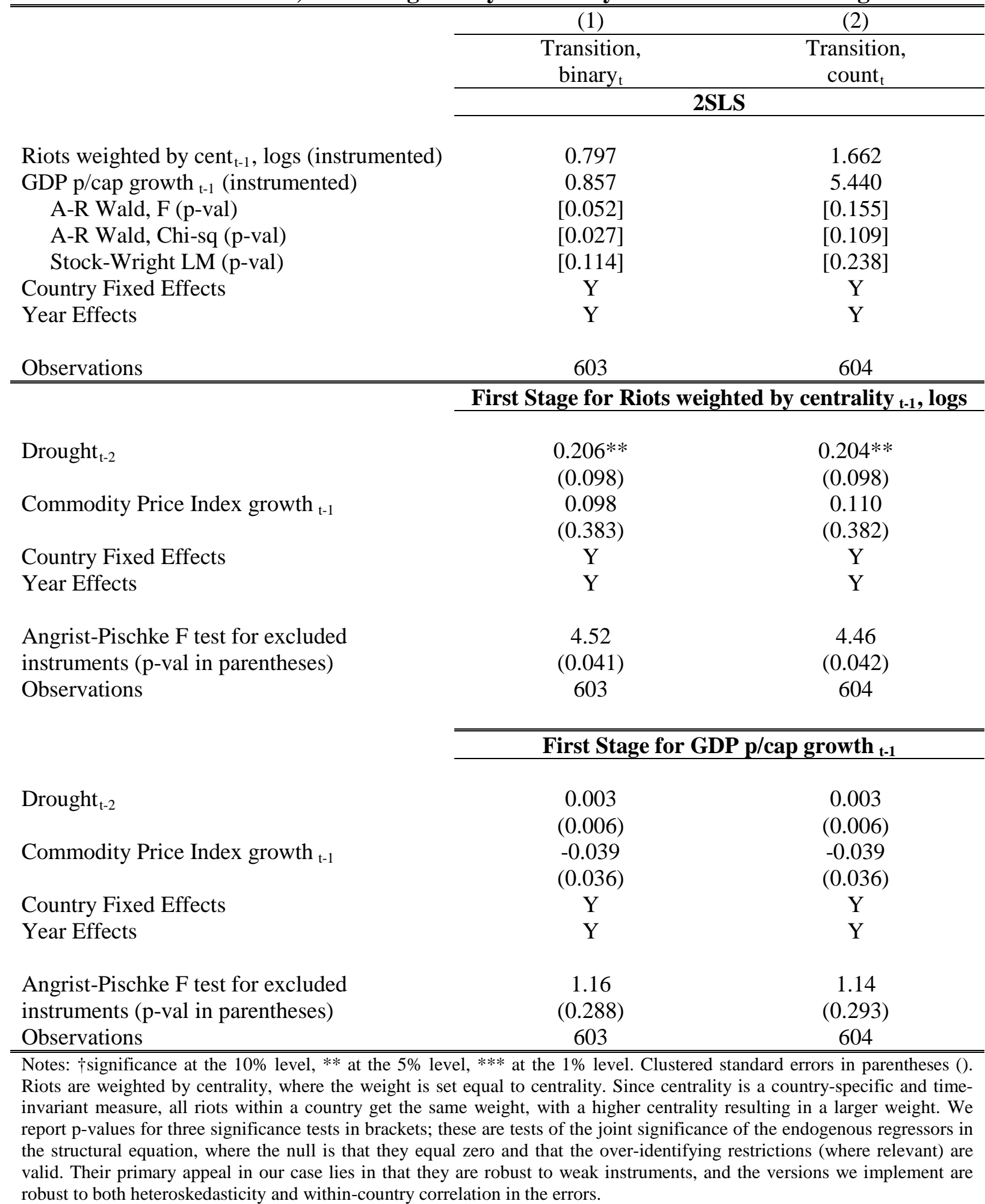


Table A11: Dynamic Specification, Riots weighted by Centrality and Democratic Change

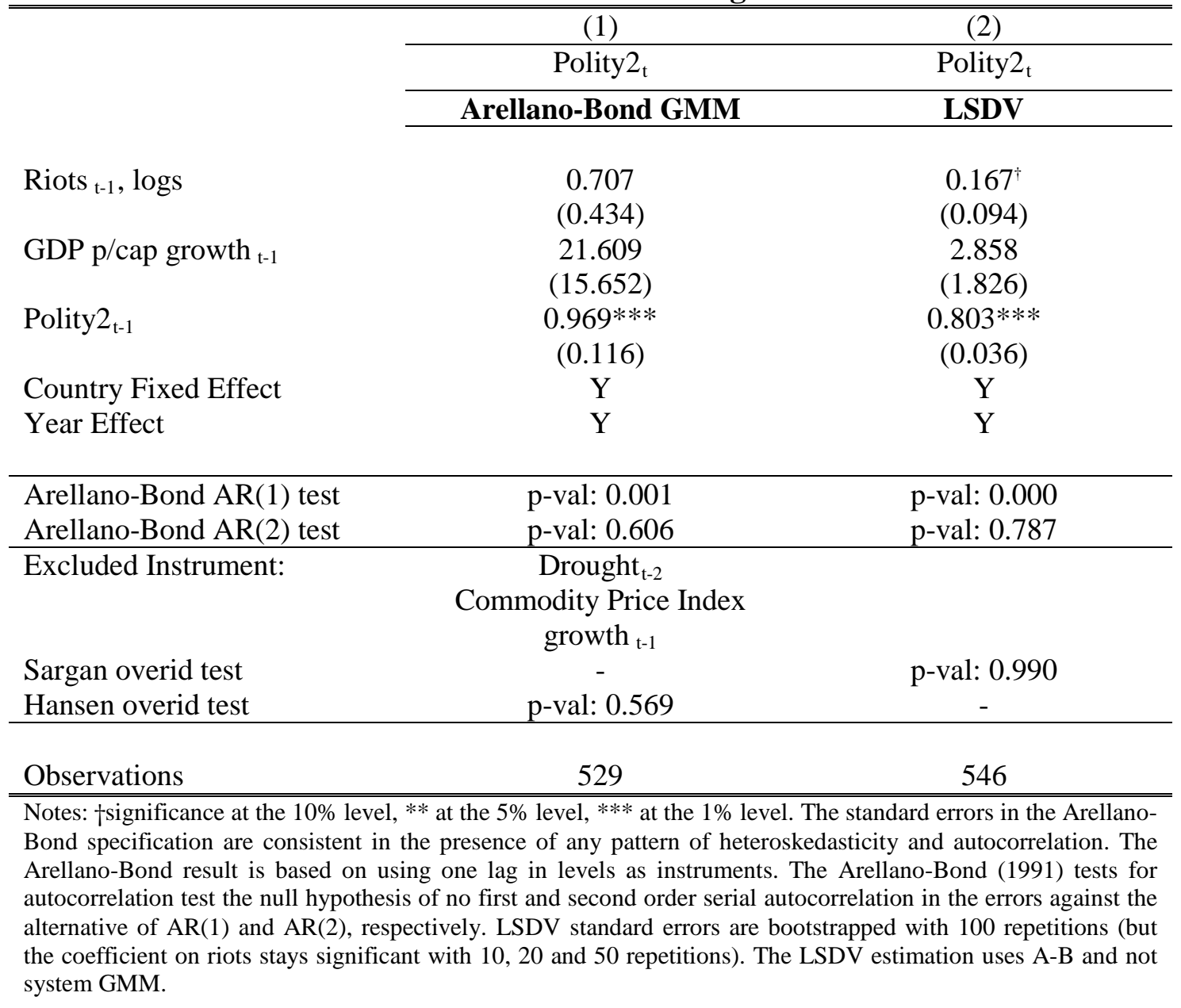




\section{Supplementary appendix}

This appendix contains a short narrative of what happened during each of the 43 regime transitions in our sample.

We classify them into three categories

1) Type 1: Regime transitions where democratic concessions by the incumbent government played a role in the transition.

2) Type 2: Regime transitions triggered by an election or a coup.

3) Type 3: Regime transitions that were anti-democratic.

The main sources used to construct the narrative are Encyclopaedia Britannica (http://www.britannica.com/) and Wikipedia (http://en.wikipedia.org/wiki). Statements in quotation marks are abstracts from the country entry in Encyclopaedia Britannica or Wikipedia.

\begin{tabular}{|c|c|c|c|}
\hline Country year & What & Type & Source \\
\hline Zambia, 2001 & $\begin{array}{l}\text { "In } 2000 \text { the suggestion was made within the MMD that the } \\
\text { constitution should be amended to permit Chiluba to stand for } \\
\text { a third term in the } 2001 \text { elections, unleashing a bitter and } \\
\text { divisive debate within the party which led to the demotion or } \\
\text { expulsion of members opposing an amendment. Outside the } \\
\text { party civil society bodies including trade unions, churches and } \\
\text { the Zambian Law Society rejected tampering with the two term } \\
\text { limit. Further factions broke with the MMD and formed new } \\
\text { parties, the most important of which was the Forum for }\end{array}$ & 1 & $\begin{array}{l}\text { EISA. 2014. Electoral Institute for Sustainable Democracy in } \\
\text { Africa. http://eisa.org.za/WEP/zamoverview7.htm. } \\
\text { Britannica }\end{array}$ \\
\hline
\end{tabular}




\begin{tabular}{|c|c|c|c|}
\hline & $\begin{array}{l}\text { Democracy Development (FDD) under Christon Tembo. In the } \\
\text { end Chiluba bowed to pressure from within and without the } \\
\text { MMD and Levy Mwanawasa, who had resigned the Vice- } \\
\text { Presidency in 1993, was nominated as MMD candidate". EISA } \\
\text { (2014). } \\
\text { Comment: A concession was made to not tamper with } \\
\text { constitution. }\end{array}$ & & \\
\hline Zambia, 1996 & $\begin{array}{l}\text { "General elections were held in Zambia on } 18 \text { November } 1996 \\
\text { to elect a President and National Assembly. They were } \\
\text { boycotted by the main opposition party, the United National } \\
\text { Independence Party, together with five other allied parties, } \\
\text { following changes to the constitution which they failed to have } \\
\text { reversed following a court challenge. The changes required a } \\
\text { presidential candidate to be born to two Zambian citizens by } \\
\text { birth or descent, and National Assembly candidates to give up } \\
\text { their chieftaincy. UNIP believed this was specifically aimed at } \\
\text { their candidates, Kenneth Kaunda, whose parents were } \\
\text { Malawian and had previously served several terms as } \\
\text { president, and its vice president, a chief. Subsequently, the } \\
\text { ruling Movement for Multi-Party Democracy won a } \\
\text { comfortable victory in both elections, taking } 131 \text { of the } 150 \\
\text { elected seats in the National Assembly, and its candidate, } \\
\text { Frederick Chiluba, winning } 73 \% \text { of the vote in the presidential } \\
\text { election." Wikipedia. } \\
\text { "Corruption allegations and conflict in the government led to } \\
\text { the resignation of the several ministers and Vice-President Levy } \\
\text { Mwanawasa from the government and accusations of ethnic } \\
\text { favouritism resurfaced within the MMD. Meanwhile the } \\
\text { government continued to harass Kaunda, placing him under } \\
\text { surveillance and alleging that he was inciting revolt, while he in } \\
\text { turn urged a campaign of civil disobedience against the } \\
\text { government. In } 1996 \text { a controversial amendment was passed } \\
\text { designed to exclude Kaunda and his deputy from standing for }\end{array}$ & 3 & $\begin{array}{l}\text { EISA. 2014. Electoral Institute for Sustainable Democracy in } \\
\text { Africa. http://eisa.org.za/WEP/zamoverview7.htm. } \\
\text { Wikipedia, Zambian_general_election,_1996. } \\
\text { Britannica }\end{array}$ \\
\hline
\end{tabular}




\begin{tabular}{|c|c|c|c|}
\hline & $\begin{array}{l}\text { election later that year. Donors responded by reducing aid, } \\
\text { while the elections were boycotted by UNIP and five other } \\
\text { parties that had allied with it over the previous five years. On a } \\
\text { poll of } 58.6 \% \text {, and in an election fraught with administrative } \\
\text { problems and allegations of abuse of the state media by the } \\
\text { MMD, the MMD won } 131 \text { of the seats, independents } 10 \text { and } \\
\text { the remaining } 9 \text { went to three small parties. Chiluba easily } \\
\text { retained the presidency with } 72.5 \% \text { of the vote" EISA (2014) } \\
\text { Comment: Anti-democratic. }\end{array}$ & & \\
\hline
\end{tabular}




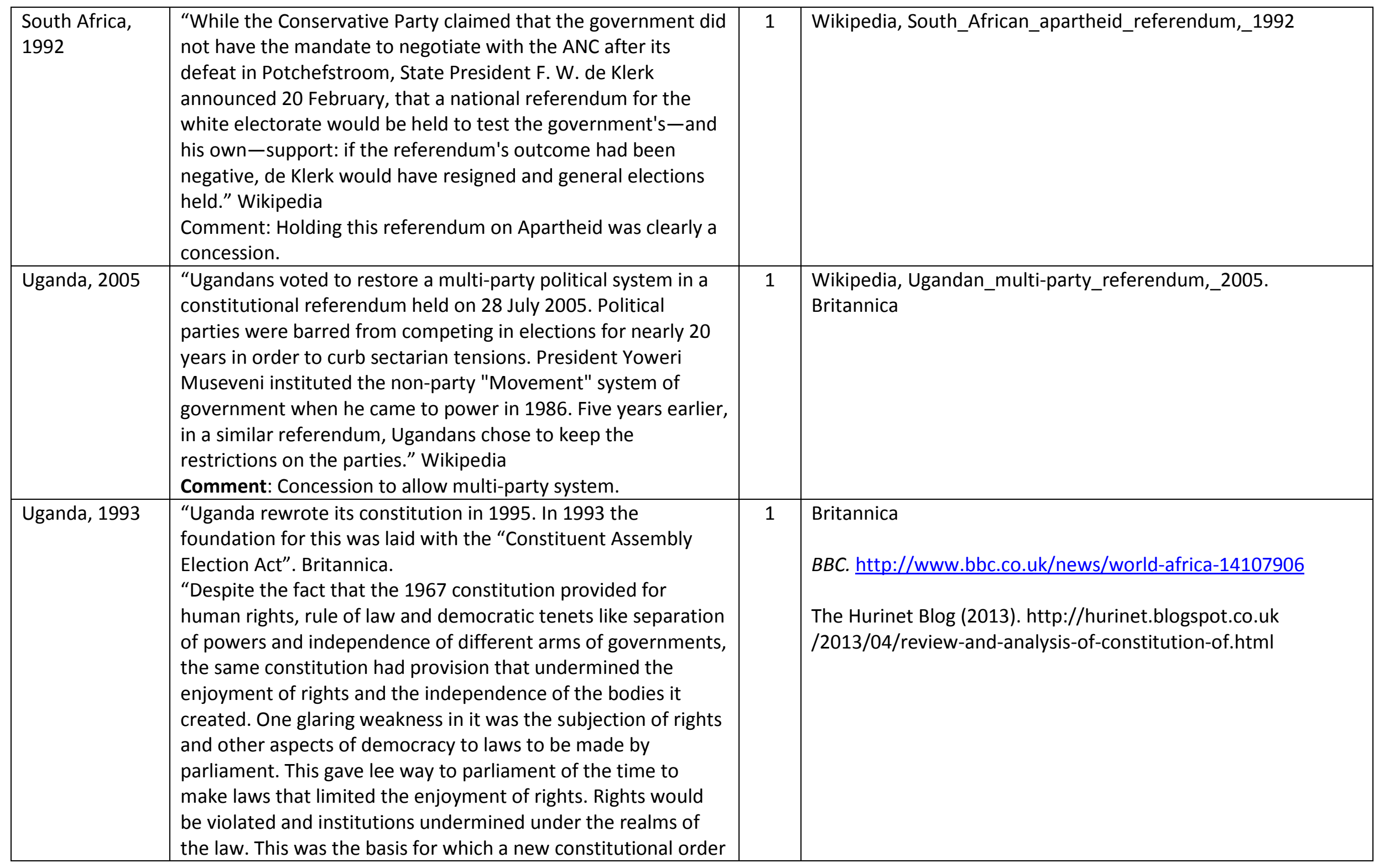




\begin{tabular}{|c|c|c|c|}
\hline & $\begin{array}{l}\text { was proposed through the Sempebwa commission of 1993/4." } \\
\text { The Hurinet Blog (2013) } \\
\text { "Since becoming president in } 1986 \text { Yoweri Museveni has } \\
\text { introduced democratic reforms at a steady pace and been } \\
\text { credited with substantially improving human rights, notably by } \\
\text { reducing abuses by the army and the police." BBC. } \\
\text { Comment: concession. }\end{array}$ & & \\
\hline Tanzania, 1995 & $\begin{array}{l}\text { "Tanzania's first multiparty elections since } 1961 \text { took place on } \\
\text { the } 29 \text { October 1995" EISA (2014). Tanzania had a one-party } \\
\text { system till this point and the election allowed for the first time } \\
\text { opposition parties to participate. Cranenburgh (1996) argues } \\
\text { "that in view of the nature and capacities of the new political } \\
\text { parties and the legal/institutional framework, the expansion of } \\
\text { both choice and representation is very limited." } \\
\text { Comment: Concession. }\end{array}$ & 1 & $\begin{array}{l}\text { EISA. 2014. Electoral Institute for Sustainable Democracy in } \\
\text { Africa. } \\
\text { http://eisa.org.za/WEP/tan1995election2.htm } \\
\text { Oda van Cranenburgh, 1996. Tanzania's } 1995 \text { Multi-Party } \\
\text { Elections: The Emerging Party System Party Politics 2: 535-547. } \\
\text { Britannica }\end{array}$ \\
\hline Togo, 1991 & $\begin{array}{l}\text { "On } 5 \text { October 1990, the trial of students who handed out anti- } \\
\text { government tracts sparked riots in Lomé. Anti-government } \\
\text { demonstrations and violent clashes with the security forces } \\
\text { marked the months that followed. In April 1991, the } \\
\text { government began negotiations with newly formed opposition } \\
\text { groups and agreed to a general amnesty that permitted exiled } \\
\text { political opponents to return to Togo. After a general strike and } \\
\text { further demonstrations, the government and opposition signed } \\
\text { an agreement to hold a "national forum" on } 12 \text { June } 1991 \text {. The } \\
\text { national forum, dominated by opponents of President } \\
\text { Eyadéma, opened in July } 1991 \text { and immediately declared itself } \\
\text { to be a sovereign "National Conference." Although subjected to } \\
\text { severe harassment from the government, the conference } \\
\text { drafted an interim constitution calling for a 1-year transitional } \\
\text { regime tasked with organizing free elections for a new } \\
\text { government." Wikipedia. } \\
\text { Comment: Concession. }\end{array}$ & 1 & $\begin{array}{l}\text { Britannica } \\
\text { Wikipedia } \\
\text { http://en.wikipedia.org/wiki/History_of_Togo }\end{array}$ \\
\hline
\end{tabular}




\begin{tabular}{|c|c|c|c|}
\hline Chad, 1991 & $\begin{array}{l}\text { "Habré continued to face threats to his regime. In April } 1989 \\
\text { the interior minister, Brahim Mahamot Itno, and two key } \\
\text { military advisers, Hassan Djamouss and Idriss Déby, were } \\
\text { suspected of plotting to overthrow Habré. Itno was arrested } \\
\text { and Djamouss was killed, but Déby escaped and began new } \\
\text { attacks a year later. By late } 1990 \text { his Movement for Chadian } \\
\text { National Salvation forces had captured Abéché, and Habré fled } \\
\text { the country. Déby and his forces then took N'Djamena, the } \\
\text { capital. Déby suspended the constitution and formed a new } \\
\text { government with himself as president. Although it was } \\
\text { reported that he had received arms from Libya, he denied } \\
\text { Libyan involvement and promised to establish a multiparty } \\
\text { democracy in Chad. Déby's takeover of the government was } \\
\text { not without resistance. In } 1991 \text { and } 1992 \text { there were several } \\
\text { attacks and coup attempts by opposition forces, many of whom } \\
\text { were still aligned with Habré, but Déby maintained his grip on } \\
\text { the government and the country. A national conference was } \\
\text { held in } 1993 \text { to establish a transitional government, and Déby } \\
\text { was officially designated interim president. In } 1996 \text { a new } \\
\text { constitution was approved and Déby was elected president in } \\
\text { the first multiparty presidential elections held in Chad's history. } \\
\text { Peace was still fragile". Britannica. } \\
\text { Comment: coup/overthrow. }\end{array}$ & 2 & $\begin{array}{l}\text { Britannica. } \\
\text { http://www.britannica.com/ EBchecked/topic } \\
\text { 1104144/Chad/278146/Continuing-conflict }\end{array}$ \\
\hline $\begin{array}{l}\text { Sierra Leone, } \\
1996\end{array}$ & $\begin{array}{l}\text { Brutal civil war in the 1990s. "Strasser was ousted in another } \\
\text { military coup in January } 1996 \text { after it was feared that he would } \\
\text { not transfer power to a civilian government, as originally } \\
\text { promised. Brig. Gen. Julius Maada Bio briefly assumed control } \\
\text { of the government with the pledge that elections would soon } \\
\text { be held. The RUF, however, requested that elections be } \\
\text { postponed until it could reach a peace agreement with the } \\
\text { government; this request was rebuffed, and the RUF intensified } \\
\text { its violent campaign. Nonetheless, elections were still held: } \\
\text { Ahmad Tejan Kabbah of the Sierra Leone People's Party won }\end{array}$ & 2 & $\begin{array}{l}\text { Britannica. } \\
\text { http://www.britannica.com44 } \\
\text { /EBchecked/topic/543356/Sierra-Leone } \\
\text { /274792/Civil-war }\end{array}$ \\
\hline
\end{tabular}




\begin{tabular}{|c|c|c|c|}
\hline & $\begin{array}{l}\text { the presidential election and took office on March 29, 1996. A } \\
\text { peace agreement between Kabbah and RUF leader Sankoh, } \\
\text { known as the Abidjan Agreement, was reached later that year } \\
\text { in November, but it was not successfully implemented." The } \\
\text { civil war continued and a sequence of coups followed. "The } \\
\text { AFRC was overthrown in February } 1998 \text { by Economic } \\
\text { Community of West African States Monitoring Group } \\
\text { (ECOMOG) troops, who intervened with the support of the } \\
\text { international community. President Kabbah's government was } \\
\text { restored in March, but ECOMOG and government troops } \\
\text { continued to battle rebel forces until July 1999, when another } \\
\text { peace accord-the Lomé Agreement-was signed. The Lomé } \\
\text { Agreement proposed a power-sharing plan that included } \\
\text { Sankoh and other rebels in the government and required the } \\
\text { RUF and the AFRC forces to surrender their weapons." } \\
\text { Britannica. } \\
\text { Comment: Coup. }\end{array}$ & & \\
\hline
\end{tabular}




\begin{tabular}{|c|c|c|c|}
\hline & $\begin{array}{l}\text { power, a significant event on the African continent. He was } \\
\text { reelected in 2007." Britannica. } \\
\text { Comment: election. }\end{array}$ & & \\
\hline Sudan, 2002 & $\begin{array}{l}\text { "The Sudan Peace Act (Pub.L. 107-245) is a United States } \\
\text { federal law sponsored by Thomas Tancredo condemning Sudan } \\
\text { for genocide. President George W. Bush signed the Act into law } \\
\text { on October 21, 2002. } \\
\text { The Act was passed to facilitate a comprehensive solution to } \\
\text { the Second Sudanese Civil War, and condemns violations of } \\
\text { human rights on all sides of the conflict." Wikipedia. } \\
\text { "However, following the Second Sudanese Civil War (1983- } \\
\text { 2005) and the now-low-scale war in Darfur, Sudan is widely } \\
\text { recognized as an authoritarian state where all effective political } \\
\text { power is obtained by President Omar al-Bashir and the ruling } \\
\text { National Congress Party (NCP). In 1993, Sudan was transformed } \\
\text { into an Islamic authoritarian single-party state as al-Bashir } \\
\text { abolished the Revolutionary Command Council and created the } \\
\text { National Islamic Front (NIF) with a new parliament and } \\
\text { government obtained solely by members of the NIF. At the } \\
\text { same time, the structure of regional administration was } \\
\text { replaced by the creation of twenty-six states, each headed by a } \\
\text { governor, thus making Sudan a federal republic. Executive } \\
\text { posts are divided between the NCP, the SPLA, the Sudanese } \\
\text { Eastern Front and factions of the Umma Party and Democratic } \\
\text { Unionist Party (DUP). According to the new } 2005 \text { constitution, } \\
\text { the bicameral National Legislature is the official Sudanese } \\
\text { parliament and is divided between two chambers - the } \\
\text { National Assembly, a lower house with } 450 \text { seats, and the } \\
\text { Council of States, an upper house with } 50 \text { seats. Thus the } \\
\text { parliament consists of } 500 \text { appointed members altogether, } \\
\text { where all are indirectly elected by state legislatures to serve } \\
\text { six-year terms." Wikipedia. }\end{array}$ & 1 & $\begin{array}{l}\text { Wikipedia: } \\
\text { http://en.wikipedia.org/wiki/Sudan_Peace_Act } \\
\text { http://en.wikipedia.org/wiki/Sudan } \\
\text { Britannica } \\
\text { http://www.britannica.com/EBchecked/topic } \\
\text { /571417/Sudan/24328/Nimeiris-overthrow-and-its-aftermath }\end{array}$ \\
\hline
\end{tabular}




\begin{tabular}{|c|c|c|c|}
\hline & $\begin{array}{l}\text { "The RCC ruled until 1993. That year it oversaw the transition } \\
\text { from military rule to a civilian government. Nonetheless, it was } \\
\text { a civilian government in which the NIF was securely in power, } \\
\text { as the RCC appointed Bashir to the presidency of the new } \\
\text { government before disbanding. The first presidential and } \\
\text { legislative elections since the } 1989 \text { coup were held in 1996; } \\
\text { Bashir won the presidency and was also reelected in 2000. The } \\
\text { ostensible transformation of the government continued with a } \\
1998 \text { referendum in which a new constitution was } \\
\text { overwhelmingly approved. The introduction of multiparty } \\
\text { politics in 1999, although viewed with pessimism by many, also } \\
\text { seemed to support the transition to a more democratic } \\
\text { approach to government. The partial suspension of the new } \\
\text { constitution later that year, however, tempered optimism, as it } \\
\text { appeared Sudan was clinging to an authoritarian regime. Also } \\
\text { that year, Sudan began to export oil, providing the opportunity } \\
\text { to bring in much-needed revenue to the country's blighted } \\
\text { economy." Britannica. } \\
\text { Comment: concession to opponents in a civil war. }\end{array}$ & & \\
\hline
\end{tabular}




\begin{tabular}{|c|c|c|c|}
\hline & Comment: anti-democratic & & \\
\hline Niger, 1996 & $\begin{array}{l}\text { Military coup. See notes above. } \\
\text { Comment: Anti-democratic. }\end{array}$ & 3 & Britannica \\
\hline Niger, 1991 & $\begin{array}{l}\text { "Upon Kountché's death in 1987, he was succeeded by his Chief } \\
\text { of Staff and cousin, Col. Ali Saibou. Saibou liberalized some of } \\
\text { Niger's laws and policies, and promulgated a new constitution. } \\
\text { He released political prisoners, including Diori and his old } \\
\text { political nemesis Djibo Bakary. However, President Saibou's } \\
\text { efforts to control political reforms failed in the face of union }\end{array}$ & 1 & $\begin{array}{l}\text { Wikipedia } \\
\text { http://en.wikipedia.org/wiki/History_of_Niger }\end{array}$ \\
\hline
\end{tabular}




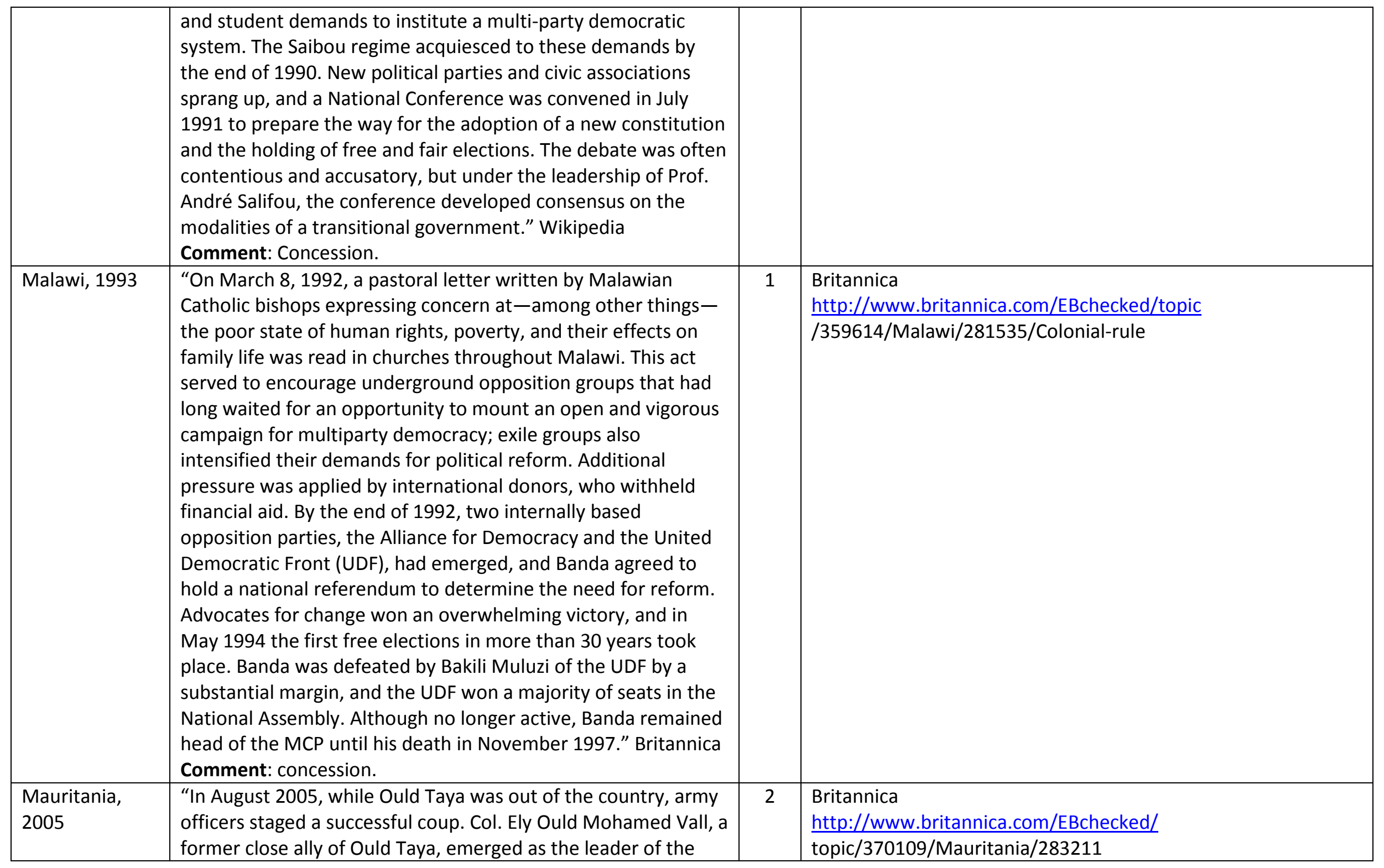




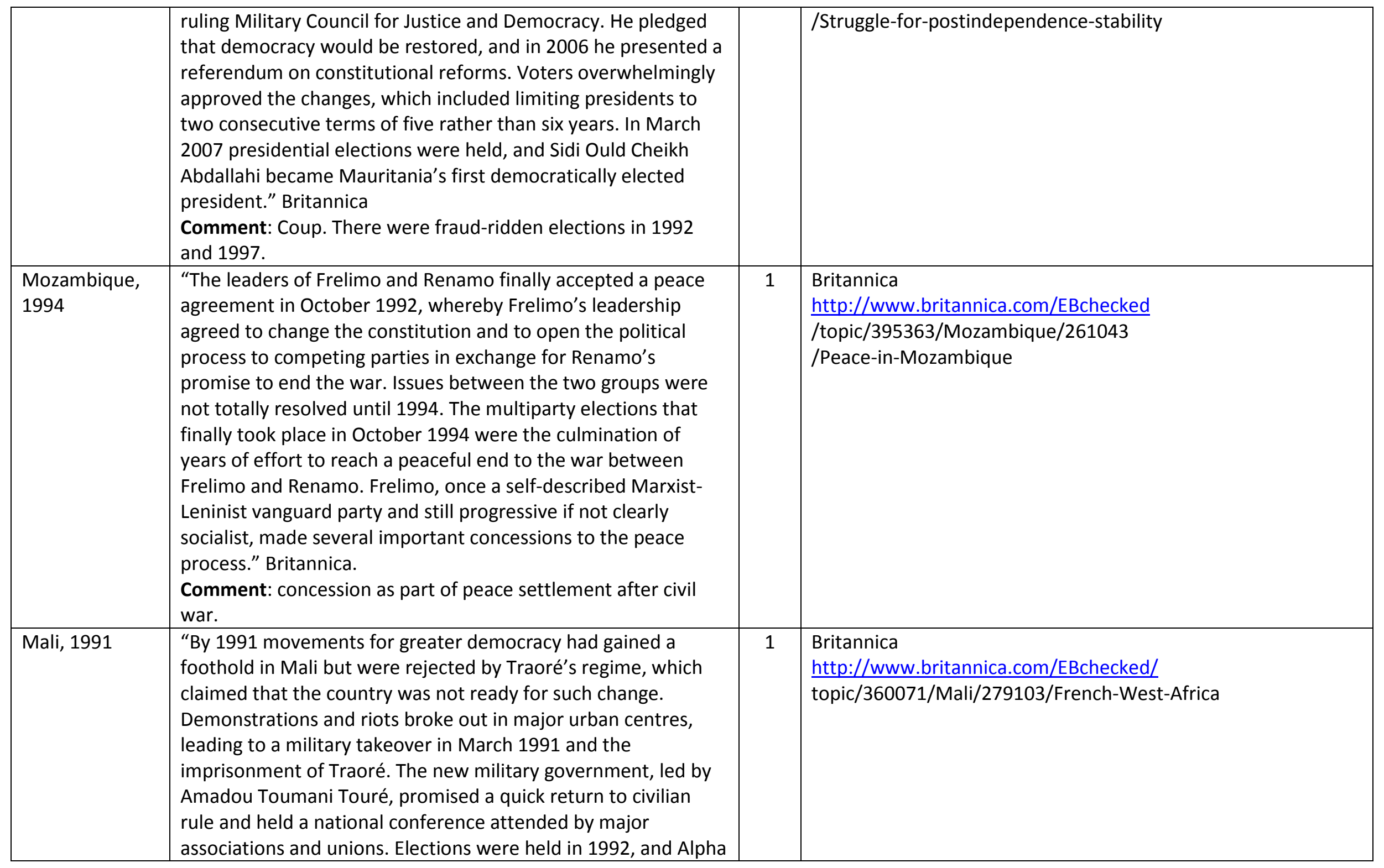




\begin{tabular}{|c|c|c|c|}
\hline & $\begin{array}{l}\text { Konaré, a prominent civilian intellectual, won the presidency." } \\
\text { Britannica. } \\
\text { Comment: concession }\end{array}$ & & \\
\hline $\begin{array}{l}\text { Madagascar, } \\
1991\end{array}$ & $\begin{array}{l}\text { "In February } 1989 \text { the main opposition groups joined to form } \\
\text { an alliance, and people and organizations that had formerly } \\
\text { aligned with the regime began increasingly to withdraw their } \\
\text { support. Although Ratsiraka was reelected in March 1989, the } \\
\text { election results gave rise to a round of protests that would } \\
\text { eventually lead to his ouster and the end of the Second } \\
\text { Republic. A call by the Council of Malagasy Churches issued in } \\
\text { August } 1989 \text { for the removal of socialist vocabulary from the } \\
\text { constitution, as well as for an end to the FNDR's monopoly on } \\
\text { political life, received wide support. The government } \\
\text { responded with a series of conciliatory gestures. At first the } \\
\text { membership of the FNDR was expanded, and then, in March } \\
\text { 1990, the constitution was amended to allow the formation of } \\
\text { political groups that were not members of the Front. Another } \\
\text { opposition alliance, the Vital Forces (Forces Vives; FV), was } \\
\text { created under the leadership of Albert Zafy, a professor at the } \\
\text { University of Madagascar. Demonstrations favouring } \\
\text { constitutional change were held, and discussions about a } \\
\text { possible revision of the constitution continued without yielding } \\
\text { any agreement. In June } 1991 \text { the FV announced the creation of } \\
\text { a provisional counter-government; this was followed by more } \\
\text { demonstrations and a general strike. In August the presidential } \\
\text { guard fired upon a demonstration in front of the presidential } \\
\text { palace; several people were killed, and others, including Zafy, } \\
\text { were wounded. Important aid donors, France among them, } \\
\text { called for an end to the instability. A power-sharing agreement } \\
\text { between Ratsiraka and the opposition was reached in October } \\
\text { and opened the way for negotiations on a new constitution. } \\
\text { Under the terms of the power-sharing agreement, Ratsiraka } \\
\text { continued as president and Zafy took office as head of a newly }\end{array}$ & 1 & $\begin{array}{l}\text { Britannica } \\
\text { http://www.britannica.com/EBchecked/topic/355562 } \\
\text { /Madagascar/279551/The-Second-Republic }\end{array}$ \\
\hline
\end{tabular}




\begin{tabular}{|c|c|c|c|}
\hline & $\begin{array}{l}\text { created High State Authority." } \\
\text { Comment: Concession. }\end{array}$ & & \\
\hline Kenya, 2002 & $\begin{array}{l}\text { "Moi announced in } 2002 \text { that he would not run again for the } \\
\text { presidency, and Uhuru Kenyatta, son of Jomo Kenyatta, was } \\
\text { chosen to be KANU's presidential candidate. Kibaki, this time } \\
\text { representing a coalition of opposition groups (the National } \\
\text { Rainbow Coalition [NARC]), soundly defeated Kenyatta in the } \\
2002 \text { presidential elections, thus ending KANU's long period of } \\
\text { uninterrupted rule." Britannica } \\
\text { "In 2002, Moi was constitutionally barred from running, and } \\
\text { Mwai Kỉbakĭ, running for the opposition coalition "National } \\
\text { Rainbow Coalition" - NARC, was elected President. Anderson } \\
\text { (2003) reports the elections were judged free and fair by local } \\
\text { and international observers, and seemed to mark a turning }\end{array}$ & 1 & $\begin{array}{l}\text { Britannica } \\
\frac{\text { http://www.britannica.com/EBchecked/topic/315078 }}{\text { /Kenya/259596/Kenya-in-the-21st-century }} \\
\text { Anderson, David M. (2003). "Kenya's Elections 2002 - The } \\
\text { Dawning of a New Era?". African Affairs } 102 \text { (407): 331-342. }\end{array}$ \\
\hline
\end{tabular}




\begin{tabular}{|c|c|c|c|}
\hline & $\begin{array}{l}\text { point in Kenya's democratic evolution." Anderson (2003) } \\
\text { Comment: Moi was constitutionally prevented from running } \\
\text { and he accepted this. We interpret this as a concession. }\end{array}$ & & \\
\hline Kenya, 1997 & $\begin{array}{l}\text { "Increasingly, however, Western financial aid came to be tied } \\
\text { to demands for political and economic reforms. It was for this } \\
\text { reason that in December } 1991 \text { Moi finally accepted a } \\
\text { constitutional amendment that reinstated multiparty elections. } \\
\text { When elections were held the following December, however, } \\
\text { Moi was reelected, and, with the opposition divided, KANU } \\
\text { won a strong majority in the National Assembly. One } \\
\text { opposition party, Forum for the Restoration of Democracy } \\
\text { (FORD), had been founded in } 1991 \text { but by } 1992 \text { had split into } \\
\text { two factions: FORD-Kenya, led by Odinga until his death in } \\
\text { 1994, and FORD-Asili, headed by Kenneth Matiba. } \\
\text { Kibaki, who had left the government late in 1991, became the } \\
\text { official leader of the opposition after elections in 1997. Many } \\
\text { Kenyans had hoped that the various opposition parties would } \\
\text { cooperate and field a single candidate who would oust Moi, but } \\
\text { there were more than eight on the ballot. Moi, the incumbent, } \\
\text { used the preexisting political network and won by a large } \\
\text { margin. Kibaki challenged the results in court, but his case was } \\
\text { dismissed. When appointing his cabinet, Moi selected KANU } \\
\text { members and continued to ignore the opposition. However, in } \\
\text { July } 1999, \text { in an apparent change of heart, Moi made Njonjo } \\
\text { chairman of the Kenya Wildlife Services and Richard Leakey } \\
\text { head of the civil service and permanent secretary to the } \\
\text { cabinet. Leakey's popularity was cited as the main reason Moi } \\
\text { appointed him to this post; the appointment was also seen as } \\
\text { Moi's way of showing Kenya's commitment to tackling the } \\
\text { issues of corruption and gross mismanagement in the } \\
\text { government." Wikipedia } \\
\text { "In democratic, multiparty elections in } 1992 \text { and } 1997, \text { Daniel } \\
\text { arap Moi won re-election." Anderson (2003). }\end{array}$ & 2 & $\begin{array}{l}\text { Anderson, David M. (2003). "Kenya's Elections 2002 - The } \\
\text { Dawning of a New Era?". African Affairs } 102 \text { (407): 331-342. } \\
\text { Wikipedia } \\
\text { http://en.wikipedia.org/wiki/Kenya\#cite_note-55 }\end{array}$ \\
\hline
\end{tabular}




\begin{tabular}{|c|c|c|c|}
\hline & $\begin{array}{l}\text { Comment: } 1997 \text { was a regular multi-party election where the } \\
\text { incumbent (Moi) won. It is not an overthrow nor is there any } \\
\text { obvious concession. }\end{array}$ & & \\
\hline $\begin{array}{l}\text { Guinea-Bissau, } \\
2005\end{array}$ & $\begin{array}{l}\text { "In March } 2005 \text { lalá announced his intention to contest the } \\
\text { elections scheduled for June of that year, although both he and } \\
\text { Vieira-who had returned from exile in April-had been barred } \\
\text { from politics in } 2003 \text {. Both candidates were subsequently } \\
\text { cleared to run for office in April. The following month, lalá } \\
\text { announced that he was in fact still president and staged a brief } \\
\text { occupation of the presidential building. Defeated in the first } \\
\text { round of polling, however, he eventually backed Vieira, who } \\
\text { won a second round of elections held in July. Although } \\
\text { supporters of the opposition raised allegations of fraud, the } \\
\text { elections were declared by international observers to have } \\
\text { been free and fair." Britannica } \\
\text { Comment: Allowing the candidates to run was a concession. }\end{array}$ & 1 & $\begin{array}{l}\text { Britannica } \\
\text { http://www.britannica.com/EBchecked/ } \\
\text { topic/248853/Guinea-Bissau/281087/Independence }\end{array}$ \\
\hline $\begin{array}{l}\text { Guinea-Bissau, } \\
2003\end{array}$ & $\begin{array}{l}\text { "Despite a democratic beginning, lalá's rule became } \\
\text { increasingly repressive. Widespread discontent with the } \\
\text { deteriorating economic and political climate led to his removal } \\
\text { in a bloodless coup in September 2003. Soon after, Henrique } \\
\text { Rosa, a businessman and virtual political newcomer, was sworn } \\
\text { in as interim president. Under Rosa's transitional government, } \\
\text { legislative elections were held in 2004, moving Guinea-Bissau } \\
\text { on course toward a stable, constitutional government. While } \\
\text { forging political peace, Rosa was faced with the task of } \\
\text { rebuilding the country's infrastructure and improving the } \\
\text { economy, both severely damaged from the civil war and years } \\
\text { of political strife." Britannica } \\
\text { Comment: anti-democratic. }\end{array}$ & 3 & Britannica \\
\hline $\begin{array}{l}\text { Guinea-Bissau, } \\
1991\end{array}$ & $\begin{array}{l}\text { "In Guinea-Bissau in 1989, the ruling African Independence } \\
\text { Party of Guinea and Cape Verde (PAIGC) under the direction of } \\
\text { President João Bernardo "Nino" Vieira began to outline a } \\
\text { political liberalization program which the People's National }\end{array}$ & 1 & $\begin{array}{l}\text { Widipedia } \\
\text { http://en.wikipedia.org/wiki/Politics of Guinea-Bissau } \\
\text { Britannica } \\
\text { http://www.britannica.com/EBchecked/topic/248853/Guinea- }\end{array}$ \\
\hline
\end{tabular}




\begin{tabular}{|c|c|c|c|}
\hline & $\begin{array}{l}\text { Assembly approved in 1991. Reforms that paved the way for } \\
\text { multi-party democracy included the repeal of articles of the } \\
\text { constitution, which had enshrined the leading role of the } \\
\text { PAIGC. Laws were ratified to allow the formation of other } \\
\text { political parties, a free press, and independent trade unions } \\
\text { with the right to strike." Widipedia } \\
\text { "Guinea-Bissau made the transition to a democratic, multiparty } \\
\text { system in the early 1990s, and the country's first free legislative } \\
\text { and presidential elections were held in 1994. The PAIGC won a } \\
\text { majority of legislative seats, while Vieira narrowly won his } \\
\text { race." Britannica } \\
\text { Comment: The constitutional process gave concession. }\end{array}$ & & Bissau/281087/Independence \\
\hline Gambia, 1994 & $\begin{array}{l}\text { "In July } 1994 \text { a group of young army officers led by Capt. (later } \\
\text { Col.) Yahya Jammeh staged a bloodless coup, justifying it by } \\
\text { citing the corruption and mismanagement of Jawara and the } \\
\text { PPP. The Senegalese government did not intervene as it had } \\
\text { done in 1981, and Jawara went into exile. The military leaders } \\
\text { promised a return to civilian rule once corruption had been } \\
\text { eliminated but meanwhile ruled by proclamation. Dissent was } \\
\text { brutally repressed, and political activity was banned until } \\
\text { August 1996. Presidential elections were held late that year, } \\
\text { with elections for the National Assembly following in early } \\
\text { 1997. Jammeh, now retired from the military, was elected } \\
\text { president, and his political party, the Alliance for Patriotic } \\
\text { Reorientation and Construction, dominated the National } \\
\text { Assembly. A new constitution, approved by voters in 1996, } \\
\text { came into effect after the legislative elections." Britannica } \\
\text { Comment: Anti-democratic. }\end{array}$ & 3 & $\begin{array}{l}\text { Britannica } \\
\text { http://www.britannica.com/EBchecked/ } \\
\text { topic/224771/The-Gambia/54967/Independence }\end{array}$ \\
\hline Guinea, 1995 & $\begin{array}{l}\text { "Although a new constitution was adopted in } 1991 \text { and the first } \\
\text { multiparty elections were held in 1993, the Conté } \\
\text { government's move toward political and economic } \\
\text { liberalization was slow, and civil unrest and protest continued } \\
\text { during the 1990s. In } 1996 \text { the government survived an }\end{array}$ & 1 & $\begin{array}{l}\text { Britannica } \\
\text { http://www.britannica.com/EBchecked/topic/ } \\
248802 / \text { Guinea/55227/Independence } \\
\text { Constitution Writing \& Conflict Resolution Project (PCWCR) } \\
\text { https://www.princeton.edu/ pcwcr/reports/ }\end{array}$ \\
\hline
\end{tabular}




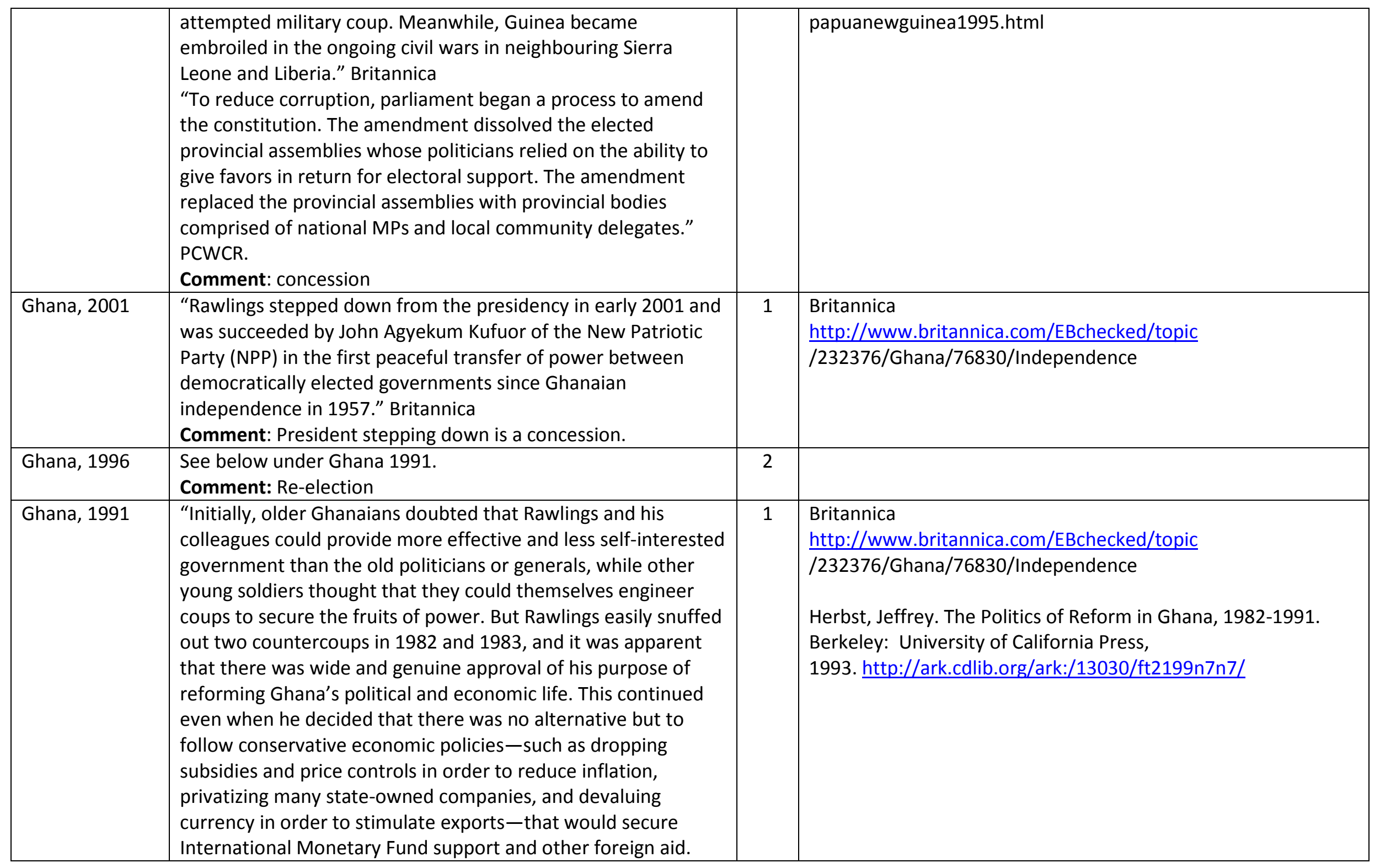




\begin{tabular}{|c|c|c|c|}
\hline & $\begin{array}{l}\text { These free-market measures revived Ghana's economy, which } \\
\text { by the early 1990s had one of the highest growth rates in } \\
\text { Africa. } \\
\text { In 1992, in the first presidential balloting held in Ghana since } \\
\text { 1979, Rawlings - representing a new party, the National } \\
\text { Democratic Congress (NDC)-was elected president. He was } \\
\text { reelected to a second term in } 1996 \text { with almost three-fifths of } \\
\text { the vote. Despite the economic progress that had been made } \\
\text { during Rawlings's rule, much of the Ghanaian press and many } \\
\text { Ghanaian professionals remained highly critical of his economic } \\
\text { policies and authoritarian political style." Britannica } \\
\text { "Finally, in the early 1990s, Ghana began to experience many of } \\
\text { the same political pressures for a return to democracy that are } \\
\text { affecting other African countries. In August 1991, the } \\
\text { government announced a program that projected a return to } \\
\text { complete civilian rule in the last quarter of 1992. Given that } \\
\text { Ghana has sustained a reform program for so long, this book } \\
\text { will be able to explore the relationship between political } \\
\text { liberalization and economic reform that is a critical question in } \\
\text { so many African countries. Indeed, this book will argue that the } \\
\text { Rawlings government decided to begin the transition to } \\
\text { democracy partially in response to the problems it encountered } \\
\text { in its attempt to reform fundamental economic institutions." } \\
\text { Herbst (1993). } \\
\text { Comment: concession. }\end{array}$ & & \\
\hline Gabon, 1990 & $\begin{array}{l}\text { "In the mid-1980s, declining petroleum prices caused an } \\
\text { economic downturn. Austerity measures imposed by the } \\
\text { government led to antigovernment demonstrations in Libreville } \\
\text { and Port-Gentil in early } 1990 \text {. This unrest led to the creation in } \\
\text { March of a national conference, which included opposition } \\
\text { groups, to discuss political reform. As a result, constitutional }\end{array}$ & 1 & $\begin{array}{l}\text { Britannica } \\
\text { http://www.britannica.com/EBchecked/ } \\
\text { topic/223148/Gabon/40751/Gabon-since-independence }\end{array}$ \\
\hline
\end{tabular}




\begin{tabular}{|c|c|c|c|}
\hline & $\begin{array}{l}\text { amendments adopted in May restored the multiparty system. } \\
\text { That same month the death of an opposition leader under } \\
\text { mysterious circumstances sparked violent disorders that led to } \\
\text { French military intervention at Port-Gentil to protect French } \\
\text { nationals and their property. Order was restored, and } \\
\text { implementation of the plans for political reform continued. } \\
\text { Legislative elections were held in the fall, and, although } \\
\text { opposition parties won seats in the new legislative assembly, } \\
\text { electoral irregularities allowed the PDG to retain a small } \\
\text { majority. The following year a new constitution was } \\
\text { promulgated in March." Britannica } \\
\text { Comment: concession }\end{array}$ & & \\
\hline Djibouti, 1999 & $\begin{array}{l}\text { "In } 1999 \text { Gouled announced that he would not stand in the } \\
\text { presidential election scheduled for April, and the RPP } \\
\text { nominated Ismail Omar Guelleh, a former cabinet secretary and } \\
\text { Gouled's nephew, as its candidate. Guelleh easily beat his } \\
\text { opponent, Moussa Ahmed Idriss, who represented a small } \\
\text { coalition of opposition parties. In } 2001 \text { the long-serving prime } \\
\text { minister Hamadou resigned for health reasons, and Guelleh } \\
\text { named Dileita Muhammad Dileita, an accomplished public } \\
\text { servant, to the post. Dileita, like his predecessor, was an Afar, } \\
\text { and Guelleh's appointment of him to the post maintained the } \\
\text { balance of power between the Afars and Somali Issas that } \\
\text { Gouled had established after independence." Britannica } \\
\text { Comment: concession. }\end{array}$ & 1 & $\begin{array}{l}\text { Britannica } \\
\text { http://www.britannica.com/EBchecked/topic } \\
\text { L166928/Djibouti/280759/Djibouti-under-Guelleh }\end{array}$ \\
\hline $\begin{array}{l}\text { Congo, Rep. } \\
1997 \\
\end{array}$ & Comment: Anti-democratic & 3 & Britannica \\
\hline $\begin{array}{l}\text { Congo, Rep. } \\
1991\end{array}$ & $\begin{array}{l}\text { "In } 1991 \text { a new constitution was drafted, and it was adopted by } \\
\text { referendum in March 1992. Pascal Lissouba defeated Bernard } \\
\text { Kolélas and Sassou-Nguesso and acceded to the presidency } \\
\text { following elections that August. A period of shaky } \\
\text { parliamentary government ensued. Competing politicians built } \\
\text { followings by politicizing ethnic differences and sponsoring }\end{array}$ & 1 & $\begin{array}{l}\text { Britannica } \\
\text { http://www.britannica.com/EBchecked/topic/132321/Republic- } \\
\text { of-the-Congo/40726/Congo-since-independence }\end{array}$ \\
\hline
\end{tabular}




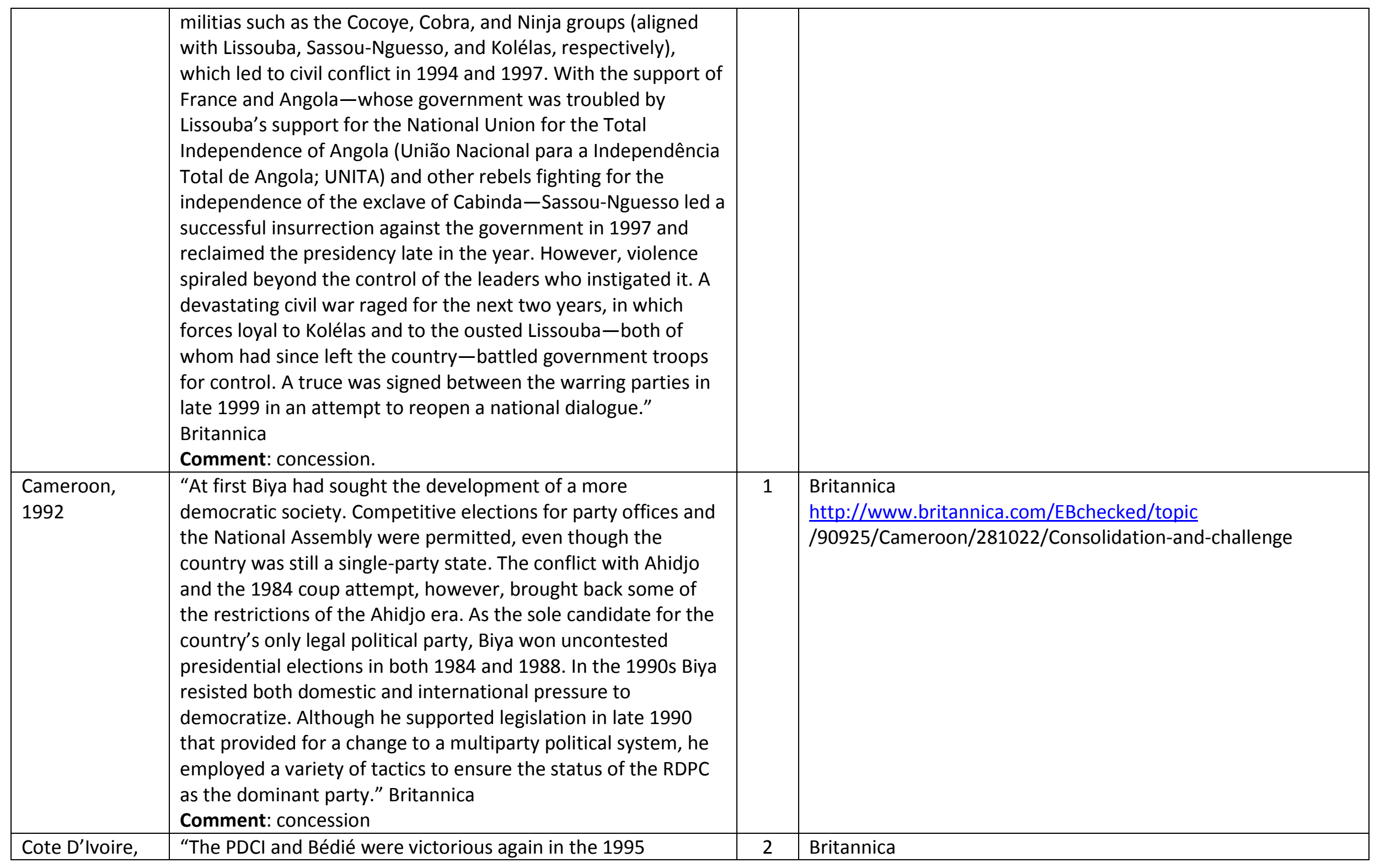




\begin{tabular}{|c|c|c|c|}
\hline 1999 & $\begin{array}{l}\text { elections that were boycotted by most of the opposition. Long- } \\
\text { standing ethnic and religious tensions continued to exist, } \\
\text { exemplified by the government's attempt to rewrite the } \\
\text { constitution to prevent certain challengers from running for } \\
\text { president. With tensions escalating, soldiers mutinied on Dec. } \\
23,1999 \text {, and Brig. Gen. Robert Gueï, a former member of } \\
\text { Houphouët-Boigny's government, took control of the country } \\
\text { the next day. Although he pledged that he would allow } \\
\text { legislative and presidential elections by October } 2000 \text { and that } \\
\text { he would not be a candidate, he changed his mind and ran for } \\
\text { president. After a controversial election in which Gueï tried to } \\
\text { manipulate the outcome, Gbagbo of the FPI was eventually } \\
\text { installed as president." Britannica } \\
\text { Comment: coup with some elections following. }\end{array}$ & & $\begin{array}{l}\text { http://www.britannica.com/EBchecked/topic/139651/Cote- } \\
\text { dlvoire/278555/Political-unrest }\end{array}$ \\
\hline $\begin{array}{l}\text { Central African } \\
\text { Republic, } 2003\end{array}$ & $\begin{array}{l}\text { "The government continued to be plagued by protests over its } \\
\text { continuing inability to pay civil servants and the military at the } \\
\text { beginning of the new millennium. Attempted military } \\
\text { overthrows that troubled the country in the mid-1990s also } \\
\text { continued into the } 21 \text { st century, culminating in the ouster of } \\
\text { Patassé in a } 2003 \text { coup by former army chief Gen. Francois } \\
\text { Bozizé. Bozizé's transitional government oversaw the drafting } \\
\text { of a new constitution that was approved in late } 2004 \text { and } \\
\text { democratic elections in 2005, in which Bozizé was elected } \\
\text { president." Britannica } \\
\text { Comment: anti-democratic. }\end{array}$ & 3 & $\begin{array}{l}\text { Britannica } \\
\text { http://www.britannica.com/EBchecked/topic/102152/Central- } \\
\text { African-Republic/254026/The-21st-century }\end{array}$ \\
\hline $\begin{array}{l}\text { Central African } \\
\text { Republic, } 1991\end{array}$ & $\begin{array}{l}\text { "By the early 1990s Central Africa had become increasingly } \\
\text { intolerant of Kolingba's authoritarian control and his lavish } \\
\text { lifestyle. Growing democratic movements elsewhere in Africa } \\
\text { had gained strength and inspired Central Africans to take } \\
\text { action. Riots broke out in 1991, after civil servants had not } \\
\text { been paid in more than eight months. It took two more years } \\
\text { for Kolingba to give in to demands for open elections, when he } \\
\text { allowed other parties to form and slate their own candidates }\end{array}$ & 1 & $\begin{array}{l}\text { Britannica } \\
\text { http://www.britannica.com/EBchecked/topic/102152/Central- } \\
\text { African-Republic/214029/Authoritarian-rule-under-Kolingba }\end{array}$ \\
\hline
\end{tabular}




\begin{tabular}{|c|c|c|c|}
\hline & $\begin{array}{l}\text { for the presidency. Although he ran for president, Kolingba was } \\
\text { rejected by the voters during the first round of balloting. } \\
\text { Instead, Ange-Félix Patassé, a former prime minister, became } \\
\text { the first democratically elected president since independence } \\
\text { as the leader of the Central African People's Liberation } \\
\text { Movement (Mouvement pour la Libération du Peuple } \\
\text { Centrafricain; MLPC)." Britannica } \\
\text { Comment: concession. }\end{array}$ & & \\
\hline $\begin{array}{l}\text { Burkina Faso, } \\
2000\end{array}$ & $\begin{array}{l}\text { "Compaoré was reelected in } 1998,2005, \text { and } 2010 \text {. His regime, } \\
\text { however, was not without opposition or controversy. } \\
\text { Unpopular political and economic developments and the } \\
\text { suspicious death in } 1998 \text { of Norbert Zongo, a prominent } \\
\text { journalist known for speaking out against Compaoré's } \\
\text { administration, contributed to periodic episodes of social and } \\
\text { political unrest that continued into the } 2000 \text { s. In October } 2003 \\
\text { several people were arrested and accused of planning a coup to } \\
\text { oust Compaoré. Meanwhile, economic troubles were } \\
\text { exacerbated by the civil war that had begun in neighbouring } \\
\text { Côte d'Ivoire in } 2002 . \text {." Britannica } \\
\text { "With French help, Blaise Compaoré seized power in a coup } \\
\text { d'état in } 1987 \text {. He overthrew his long-time friend and ally } \\
\text { Thomas Sankara, who was killed in the coup. } \\
\text { The constitution of } 2 \text { June } 1991 \text { established a semi-presidential } \\
\text { government: its parliament can be dissolved by the President } \\
\text { of the Republic, who is elected for a term of seven years. In } \\
2000, \text { the constitution was amended to reduce the presidential } \\
\text { term to five years and set term limits to two, preventing } \\
\text { successive re-election. The amendment took effect during the } \\
2005 \text { elections. If passed beforehand, it would have prevented } \\
\text { the incumbent president, Blaise Compaoré, from being } \\
\text { reelected. } \\
\text { Other presidential candidates challenged the election results. }\end{array}$ & 1 & $\begin{array}{l}\text { Britannica } \\
\text { http://www.britannica.com/EBchecked/topic } \\
\text { Wikipedia } \\
\text { http://en.wikipedia.org/wiki/Burkina Faso }\end{array}$ \\
\hline
\end{tabular}




\begin{tabular}{|l|l|l|l|}
\hline & $\begin{array}{l}\text { But, in October 2005, the constitutional council ruled that, } \\
\text { because Compaoré was the sitting president in 2000, the } \\
\text { amendment would not apply to him until the end of his second } \\
\text { term in office. This cleared the way for his candidacy in the } \\
\text { 2005 election. On 13 November, Compaoré was reelected in a } \\
\text { landslide, because of a divided political opposition." Wikipedia } \\
\text { Comment: The constitutional amendment in 2000 was a } \\
\text { concession that limited the power of the incumbent to some } \\
\text { extent. }\end{array}$ & & \\
\hline Benin, 1990 & $\begin{array}{l}\text { "The late 1980s and early 1990s were a turbulent period for } \\
\text { Benin. In 1989 Kérékou proclaimed that Marxism-Leninism } \\
\text { would no longer be the state ideology, and there followed a } \\
\text { period of transition in the direction of greater democratization, } \\
\text { including the promulgation of a new constitution in 1990 and } \\
\text { the liberalization of the economy. The first multiparty elections } \\
\text { were held in 1991, and Kérékou was defeated by Nicéphore } \\
\text { Soglo, a former cabinet member." Britannica } \\
\text { Comment: concession. }\end{array}$ & 1 & $\begin{array}{l}\text { Britannica } \\
\text { http://www.britannica.com/EBchecked/topic }\end{array}$ \\
\hline
\end{tabular}

